Article

\title{
Ore Genesis and Geodynamic Setting of Laochang Ag-Pb-Zn-Cu Deposit, Southern Sanjiang Tethys Metallogenic Belt, China: Constraints from Whole Rock Geochemistry, Trace Elements in Sphalerite, Zircon U-Pb Dating and Pb Isotopes
}

\author{
Chen Wei ${ }^{1,2}$, Lin Ye ${ }^{1, *}$, Zhilong Huang ${ }^{1, *}$, Wei Gao ${ }^{1,2}$, Yusi Hu ${ }^{1,2}$, Zhenli Li ${ }^{1,2}$ \\ and Jiawei Zhang ${ }^{3}$ \\ 1 State Key Laboratory of Ore Deposit Geochemistry, Institute of Geochemistry, Chinese Academy of Sciences, \\ Guiyang 550081, China; weichen@mail.gyig.ac.cn (C.W.); gfba00@163.com (W.G.); \\ huyusi@mail.gyig.ac.cn (Y.H.); lizhenli@mail.gyig.ac.cn (Z.L.) \\ 2 University of Chinese Academy of Sciences, Beijing 100049, China \\ 3 Guizhou Geological Survey, Bureau of Geology and Mineral Exploration and Development of Guizhou \\ Province, Guiyang 550081, China; jiaweizhang@live.cn \\ * Correspondence: yelin@vip.gyig.ac.cn (L.Y.); huangzhilong@vip.gyig.ac.cn (Z.H.)
}

Received: 21 September 2018; Accepted: 30 October 2018; Published: 8 November 2018

\begin{abstract}
The Laochang Ag-Pb-Zn-Cu deposit, located in the southern margin of the Sanjiang Tethys Metallogenic Belt (STMB), is the typical Ag-Pb-Zn-Cu deposit in this region. Its orebodies are hosted in the Carboniferous Yiliu Formation volcanic-sedimentary cycle and occur as stratiform, stratoid and lenticular. Whether or not the stratabound ore belong to the volcanogenic massive sulfide (VMS) deposit remains unclear and controversial. In this paper, the whole rock geochemistry, trace elements in sphalerite, $\mathrm{U}-\mathrm{Pb}$ zircon chronology and $\mathrm{Pb}$ isotopes were investigated, aiming to provide significant insights into the genesis and geodynamic setting of the Laochang deposit. Lead isotope ratios of pyrite and sphalerite from the stratabound ore are 18.341 to 18.915 for ${ }^{206} \mathrm{~Pb} /{ }^{204} \mathrm{~Pb}$; 15.376 to 15.770 for ${ }^{207} \mathrm{~Pb} /{ }^{204} \mathrm{~Pb}$; and 38.159 to 39.200 for ${ }^{208} \mathrm{~Pb} /{ }^{204} \mathrm{~Pb}$ - which display a steep linear trend on $\mathrm{Pb}-\mathrm{Pb}$ diagrams. This indicates a binary mixing of lead components derived from leaching between the host volcanic rock and mantle reservoir. Sphalerite from stratabound ores is relatively enriched in $\mathrm{Fe}, \mathrm{Mn}, \mathrm{In}, \mathrm{Sn}$, and Ga-similar to typical VMS deposits. Moreover, the Carboniferous volcanic rock hosting the stratabound Ag-Pb-Zn-Cu ores has a zircon $\mathrm{U}-\mathrm{Pb}$ age of $312 \pm 4 \mathrm{Ma}$; together with previous geochronological and geological evidences, thus, we consider that the stratabound mineralization occur in the Late Paleozoic ( 323-308 Ma). Collectively, these geologic, geochemical, and isotopic data confirm that the stratabound ores should be assigned to Carboniferous VMS mineralization. In addition, volcanic rocks hosting the stratabound ore exhibit elevated high field strength elements (HFSEs, $\mathrm{Nb}, \mathrm{Ta}, \mathrm{Zr}$ and $\mathrm{Hf}$ ) abundance, slight enrichment of light rare earth element (LREE), and depletion of $\mathrm{Ba}$ and $\mathrm{Sr}$ with obvious $\mathrm{Nb}-\mathrm{Ta}$ anomalies. Such characteristics suggest that their magma is similar to typical oceanic island basalt. In addition, the oceanic island basalt (OIB)-like volcanic rocks were formed at Late Paleozoic, which could be approximately synchronous with the VMS mineralization at Laochang. Thus, it is suggested that the Laochang VMS mineralization was generated in the oceanic island setting prior to the initial subduction of the Changning-Menglian Paleo-Tethys Ocean.
\end{abstract}

Keywords: trace elements in sphalerite; U-Pb dating; geodynamic setting; Sanjiang Tethys Metallogenic Belt; Laochang Ag-Pb-Zn-Cu deposit 


\section{Introduction}

The Sanjiang Tethys Metallogenic Belt (STMB), one of the premier polymetallic belts in China (Figure 1A), is located within the eastern Himalayan-Tibetan Orogen. Numerous ore deposits of diverse genetic types and metal speciation, including volcanogenic massive sulfide (VMS), porphyry-skarn $\mathrm{Cu}-\mathrm{Mo}, \mathrm{Cu}$, and $\mathrm{Cu}-\mathrm{Au}$, orogenic $\mathrm{Au}$, and Mississippi Valley-type (MVT) Pb-Zn deposits, were formed from Paleozoic to Cenozoic. These different genetic types of ore deposit formation are closely associated with the tectonic evolution in the Sanjing region [1-5].

The Laochang Ag-Pb-Zn- $\mathrm{Cu}$ deposit is located at the southern part of the STMB, and has a proven reserve of $866,000 \mathrm{t} \mathrm{Pb}$ at $4.5 \%, 336,000 \mathrm{t} \mathrm{Zn}$ at 3.3\%, $1700 \mathrm{t} \mathrm{Ag}$ at $155 \mathrm{~g} / \mathrm{t}, 116,000 \mathrm{t} \mathrm{Cu}$ at $0.5-0.9 \%, 2.84 \mathrm{Mt}$ Pyrite and accompanying $0.8 \mathrm{t} \mathrm{Au} \mathrm{[6-8].} \mathrm{It} \mathrm{is} \mathrm{the} \mathrm{largest} \mathrm{Ag-Pb-Zn-Cu} \mathrm{deposit} \mathrm{at}$ the Changning-Menglian Suture and has been mined since the Yongle Period of the Ming Dynasty (1404 AD) [9]. Over the past four decades, several studies have been carried out on the Laochang $\mathrm{Ag}-\mathrm{Pb}-\mathrm{Zn}$-Cu deposit, most of which were published in Chinese. However, many issues, especially its ore genesis, are still controversial. The orebodies generally show stratigraphic control and the bulk chemical and $\mathrm{Nd}-\mathrm{Pb}$ isotopic data suggest that the basalt hosting the stratabound orebodies exhibit an oceanic island basalt (OIB) signature $[10,11]$. Thus, a great number of authors consider it is a syngenetic VMS deposit [12-14]. In contrast, with recent mining exposures at Laochang deposit, the Cenozoic concealed porphyry intrusion has been discovered in depth, which is spatially related to the stratabound ores. Consequently, several authors have regarded it as a magmatic-hydrothermal deposit [6,15-17]. The former hypothesis suggests that the deposit is syngenetic and generated by submarine synvolcanogenic processes $[18,19]$, whereas the latter model considers that it is epigenetic and related to concealed porphyry intrusion [20,21]. There has not been, until now, a complete understanding of the relationships between the stratabound $\mathrm{Ag}-\mathrm{Pb}-\mathrm{Zn}-\mathrm{Cu}$ mineralization, host volcanic rock and porphyry intrusion.

In this paper, we present a comparative geochronology study (U-Pb dating using zricon) for stratabound ores hosting volcanic rocks and previous studies obtained the timing of stratabound mineralization to assess their temporal relationship. We further analyze trace elements of sphalerite and $\mathrm{Pb}$ isotopic composition of sulfides (pyrite and sphalerite) from stratabound ores and ore-hosting volcanic rocks to constrain its ore origin. Lastly, we use the major and trace element of ore-hosting volcanic rocks and zircon $\mathrm{U}-\mathrm{Pb}$ dating to provide insights into the geodynamic setting of Laochang $\mathrm{Ag}-\mathrm{Pb}-\mathrm{Zn}-\mathrm{Cu}$ deposit.

\section{Geological Setting}

The Changning-Menglian Suture forms part of the STMB (Figure 1B). It has a complex history that reflects a Proto-Tethys Ocean opened during the Neoproterozoic and closed in the late Early Paleozoic $[4,11,22]$, followed by the development of the main Paleo-Tethys Ocean. The Paleo-Tethys Ocean opened during the Middle Devonian, as recorded by the Middle Devonian deep water marine cherts, Eoalbaillella lilaensis radiolarians and ophiolite complex with the zircon U-Pb ages of 349-331 Ma for gabbros $[23,24]$, and the Changning-Menglian Tethys Ocean was subducted underneath the Simao block, forming the Yunxian-Jinggu Arc in ca. 306-265 Ma [4,25-31]. During the Middle Permian-Middle Triassic, the collision and amalgamation of the Baoshan and Simao terranes resulted in the S-type Lincang granitic batholith with zircon U-Pb ages of 234-219 Ma [27,32,33] and the coeval bimodal mafic-felsic volcanic rocks with zircon U-Pb ages of 231-210 Ma located at the east of the Lincang batholith [33,34]. Since the Late Triassic Period, the generation of the peraluminous granites was most likely related to post-collisional extension, including the Bulangshan and Mengsong granitoids, and the Lincang biotite granites/monzogranites [31-36].

The Changning-Menglian Suture is an N-S trending strip $300 \mathrm{~km}$ long and $15-50 \mathrm{~km}$ wide, sandwiched between the Simao block to the east and the Baoshan block to the west (Figure 1C). The overall stratigraphic succession is dominated by a Proterozoic basement complex that unconformably overlain Paleozoic to Quaternary sediments. The basement comprises upper Proterozoic epimetamorphic 
rock series. The oldest rock, Devonian in age, are deep oceanic sediments comprised by siliceous rock, silica mudstone and greywacke unconformably overlain by Carboniferous shallow marine limestone intercalated by volcanic rocks. The volcanic rocks are mostly regarded as sea-mounts and/or oceanic islands in origin [37,38]. The Permian series consist of up to $730 \mathrm{~m}$ of massive detrital and bioclastic limestone and dolomite, followed by Triassic bathyal facies clastic sedimentary sequence of argillaceous slate, radiolarian bedded chert and vitric tuff [39]. The Jurassic sediment is composed of purple sand conglomerate, quartz sandstone, siltstone and mudstone, which is capped by Paleogene sand conglomerate and mudstone, and Quaternary unconsolidated sediments [10]. More details on the geology of the Changning-Menglian Suture can be found in Li et al. [11] and Deng et al. [40].

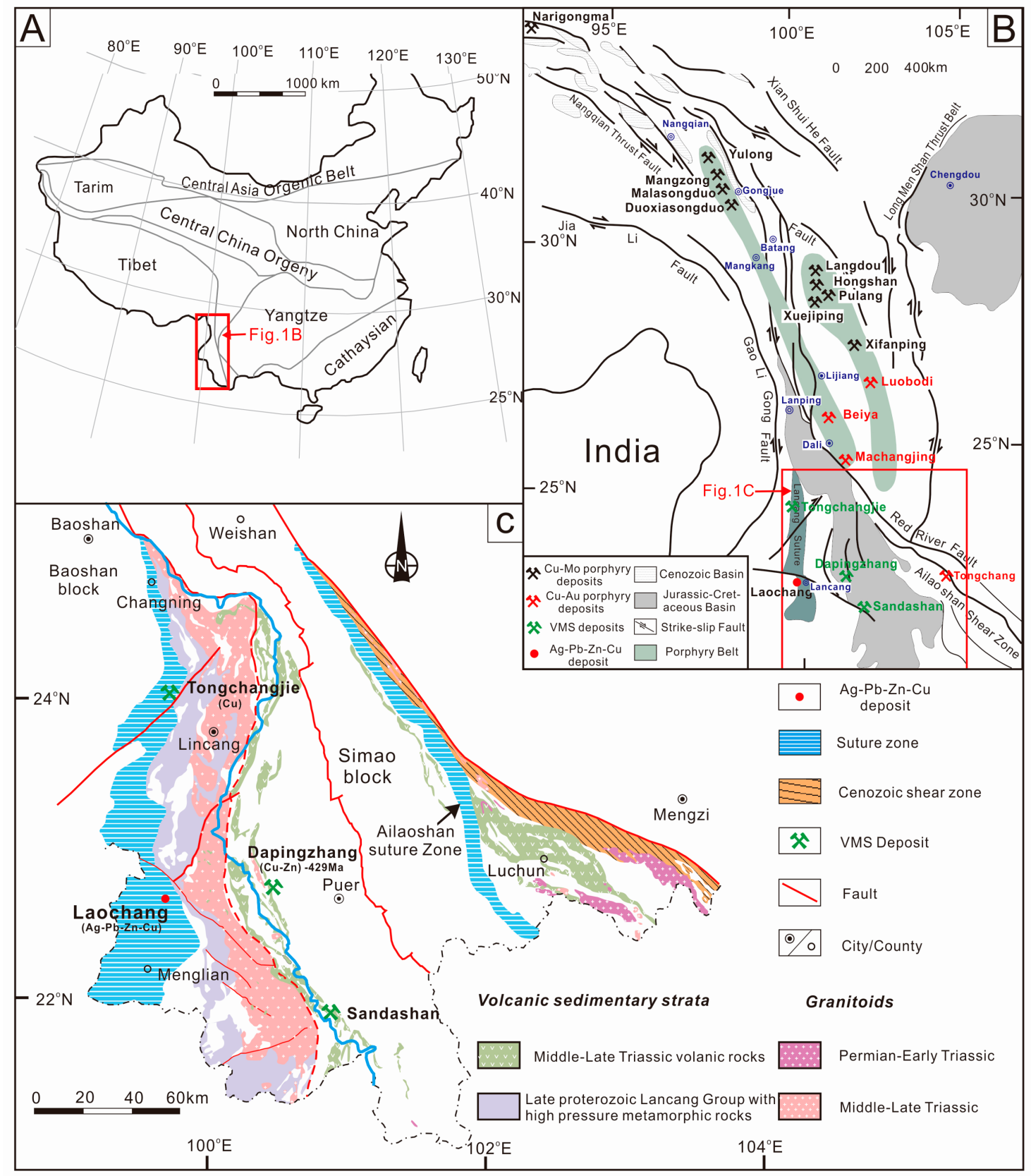

Figure 1. (A) Geotectonic framework map of China showing the location of the Sanjiang Orogen; (B) Geologic map of the Southwest Sanjiang Tethys metallogenic belt that shows the porphyry and volcanogenic massive sulfide (VMS) deposits (modified after Li et al. [8]); (C) The Lancang river zone showing the distribution of the major tectonic units, igneous rocks and location of the Laochang Ag-Pb-Zn-Cu deposit (modified after Deng et al. [3,4]). 


\section{Geology of the Laochang Deposit}

\subsection{Strata}

The Laochang deposit $\left(22^{\circ} 45^{\prime} \mathrm{N}, 99^{\circ} 44^{\prime} \mathrm{E}\right)$ is located about $30 \mathrm{~km}$ northwest of Lancang City (Figure 1C). The exposed strata in the Laochang deposit consist of Devonian, Carboniferous, Permian and Quaternary (Figure 2). The Devonian strata comprise clastic and siliceous rocks and are overlain by Carboniferous volcanic-sedimentary rocks, limestone and dolomite. The Lower Permian strata are composed of limestone, and the Quaternary is mainly red-clay sediment [41].

The stratabound $\mathrm{Ag}-\mathrm{Pb}-\mathrm{Zn}-\mathrm{Cu}$ ore is mainly hosted in the Carboniferous Yiliu Formation, which comprises volcanic rocks (45.3 vol\%; e.g., basalt, andesite and trachyte), volcaniclastic rocks (43.3 vol\%; e.g., andesitic, basaltic-andesitic, basaltic, trachytic, trachyandesitic tuff-breccia and agglomerates) and small number of siliceous rocks and limestone lenses, with a total thickness of up to $870 \mathrm{~m}$ [8]. From bottom to top, Yiliu volcanic-sedimentary cycles can include as follows (1) andesitic tuff, andesitic breccia, basaltic breccia and basaltic tuff-breccia, $>20 \mathrm{~m}$ thick; (2) basaltic breccia, basaltic tuff and massive basalt, 50-130 m thick; (3) andesite, andesitic agglomerates and andesitic breccia tuff, 60-130 m thick; (4) andesitic breccia tuff with sandstone, bioclastic limestone and tuffite, 0-120 m thick; (5) trachybasaltic, andesitic tuff with banded siliceous rocks, carbonaceous shale, and marble, $80-160 \mathrm{~m}$ thick; (6) massive basalt with trachybasaltic, andesitic tuff, 55-160 m thick; and (7) trachyandesitic, trachytic tuff with sand shale, siltstone and limestone, $>150 \mathrm{~m}$ thick $[41,42]$. The Yiliu Formation is composed of two lava-agglomerates-breccia-tuff-sedimentary basic groups, which are divided into two-small volcanic-sedimentary cycles according to comparison of the profile of the regional volcanic rocks and Laochang drills [8].

\subsection{Structure}

The orefield is characterized by a set of N- to NW-trending, steeply east dipping thrust faults that control the distribution of volcanic rocks and mineralization (Figure 2). They were reactivated later, especially in the Cenozoic India-Asia collision $[3,4,43]$ and controlled the concealed porphyry emplacement [8]. 


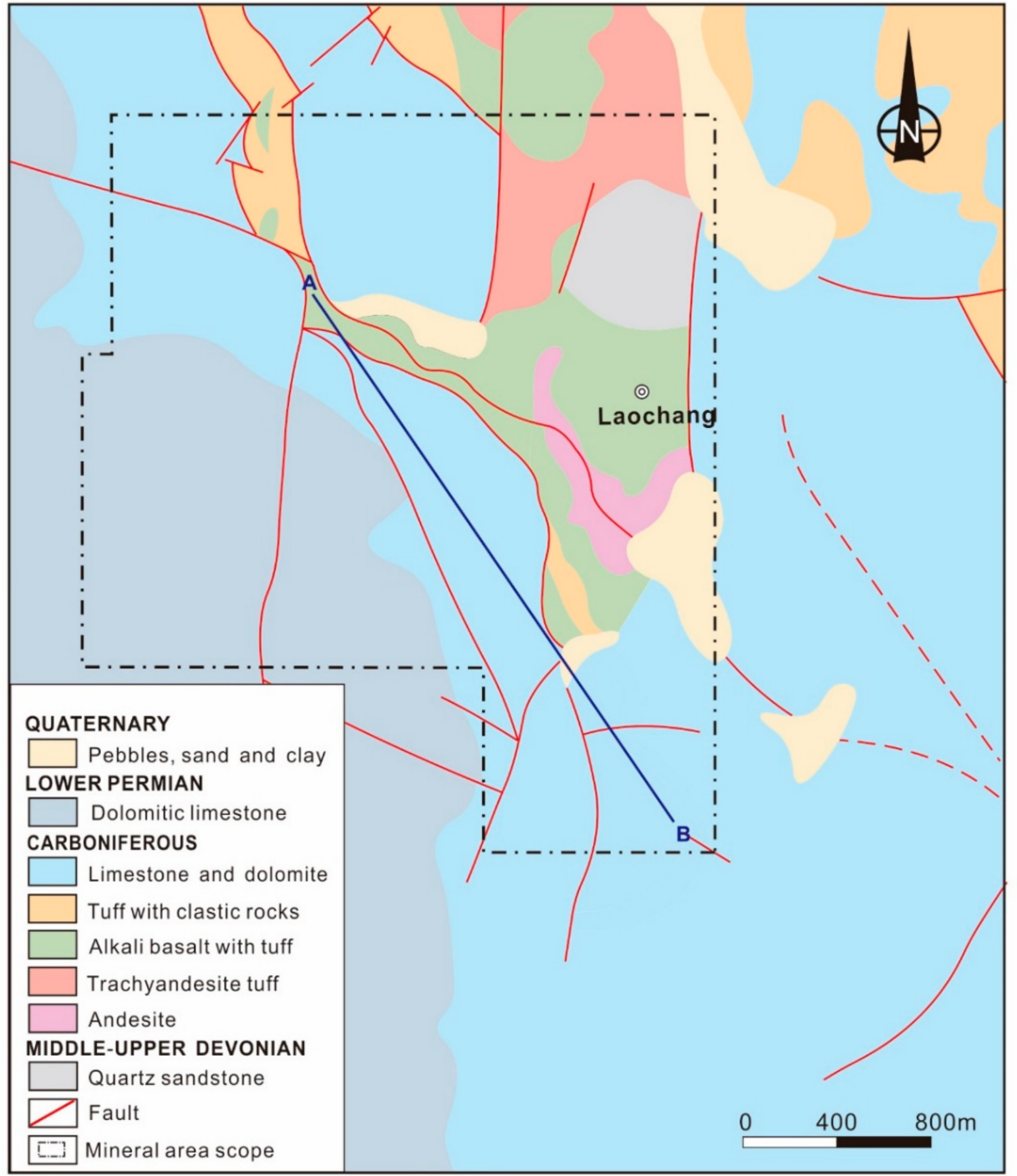

Figure 2. Geological map of the Laochang deposit (modified from Long [41]).

\subsection{Porphyry Intrusion}

Excavations in the Laochang mine resulted in the discovery of concealed porphyry intrusion, and numerous drillings have encountered granitic porphyry intrusion in the Carboniferous volcanic-sedimentary cycles (Figure 3). The granitic porphyry is grey-greyish white with porphyritic texture, which contains phenocrysts of K-feldspar (15-20 vol\%, up to $15-\mathrm{mm}$ diameter), quartz (10-15 vol\%, 2-5 mm diameter, rounded or embayed shape), plagioclase (10-15 vol\%, 2-8 mm diameter, altered by sericite and carbonate), and biotite ( $2-5 \mathrm{vol} \%)$. The groundmass comprises quartz and orthoclase. The granite porphyry show high $\mathrm{SiO}_{2}, \mathrm{~K}_{2} \mathrm{O}$ and low $\mathrm{MgO}, \mathrm{CaO}, \mathrm{FeO}, \mathrm{P}_{2} \mathrm{O}_{5}$ contents, and they belong to alkaline series [41], which is similar to the large and super large Cenozoic porphyry $\mathrm{Cu}-\mathrm{Au}-\mathrm{Mo}$ deposit in STMB. SHRIMP zircon U-Pb dating has shown that the granitic porphyry was emplaced at $44.6 \pm 1.1 \mathrm{Ma}$ [44]. In addition, geochemical data indicate that the felsic magma was produced by partial melting of mafic lower crust with input of minor amounts of mantle-derived melts [45]. 


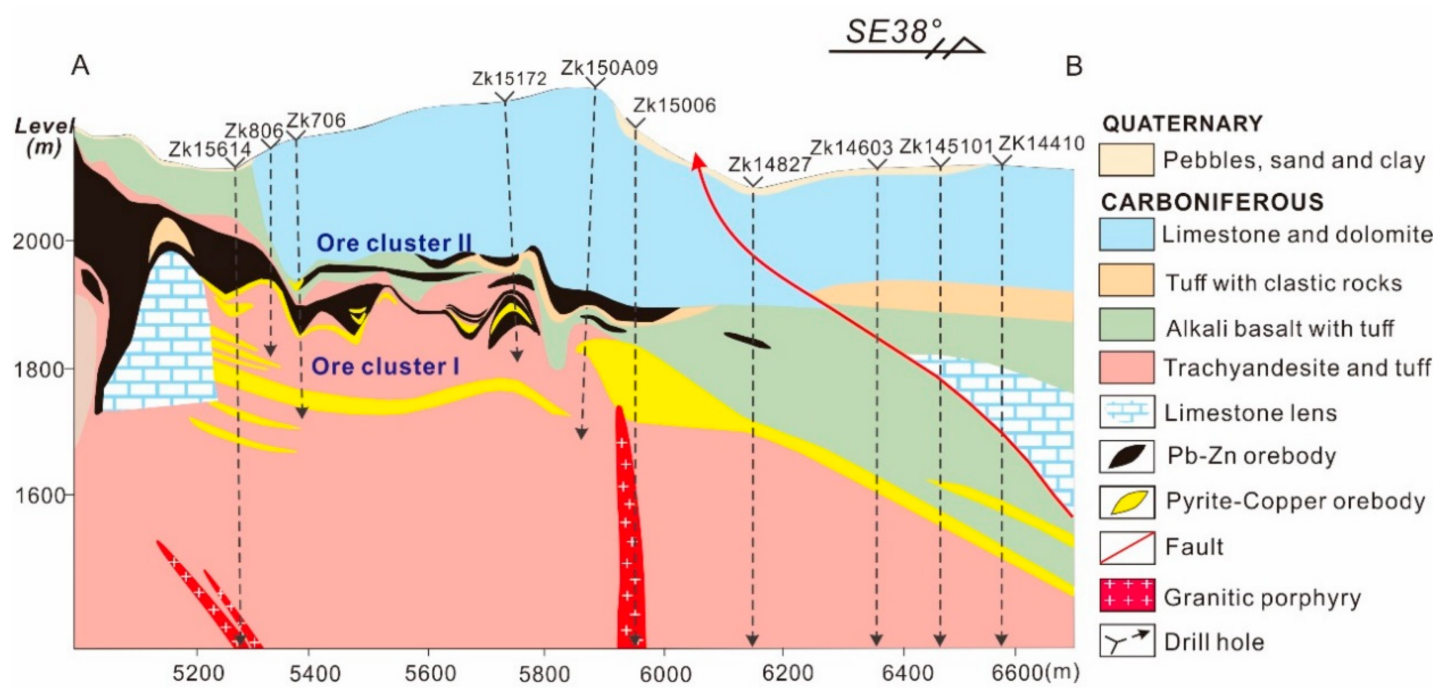

Figure 3. Geologic cross-section (A,B) showing the mineralization in the Laochang deposit (modified from Li et al. [8]).

\subsection{Sulfide Mineralization}

Stratabound ores are situated in the Carboniferous Yiliu Formation (Figure 4) and show distinctive metal zonation from bottom to top [11]. The orebodies are divided into two layers vertically, which formed mainly at the top of the first and second volcanic cycles [7,42]. In each ore cluster, numerous sulfide orebodies are stacked upwards and largely overlap in the vertical projections (Figure 3). Metal zonation from $\mathrm{Fe}-\mathrm{Cu}$ to $\mathrm{Cu}-\mathrm{Zn}-\mathrm{Pb}$ and then to $\mathrm{Ag}-\mathrm{Pb}-\mathrm{Zn}$ is present in both ore cluster and single orebody [44].

Ore cluster No. I consisting of 48 orebodies occurs in the top sequences of andesitic-trachyandesitic tuff interlayered with limestone and carbonaceous chert within the first volcanic cycle (Figure 4). These orebodies are stratiform, stratoid and lenses, which consistent with the host strata. The largest orebody No. $\mathrm{I}_{1+2}$, located in the north part of this ore cluster, is stratiform and accounts for approximately $90.6 \%$ of the sulfide ore reserve of ore cluster No. I and 30\% of Ag reserve of the total deposit. It is $875 \mathrm{~m}$ in length, 50 to $258 \mathrm{~m}$ in width with an average of $129 \mathrm{~m}$ and 3 to $23 \mathrm{~m}$ in thickness with an average of $7 \mathrm{~m}$ and has estimated metal reserves of $88,400 \mathrm{tPb}$ at $4.5 \%, 70,300 \mathrm{t} \mathrm{Zn}$ at $3.8 \%$ and $368.67 \mathrm{t} \mathrm{Ag}$ at $199.4 \mathrm{~g} / \mathrm{t} \mathrm{[41].} \mathrm{Most} \mathrm{of} \mathrm{the} \mathrm{high-grade} \mathrm{Ag}-\mathrm{Zn}-\mathrm{Pb}$ ores are distributed in the upper part of this orebody, and gradually grades into sparse disseminated sulfides and finally into pyrite-dominant sulfides downward (Figures 3 and 4). Other orebodies of ore cluster No. I occurring as lenses and sacks are mainly distributed in andesitic tuff, which are higher in metal grade, but smaller in size. In the northern part of this ore cluster, underneath the semi-horizontal stratiform Fe- $\mathrm{Zn}-\mathrm{Pb}$ orebodies are a vertical stringer zone (Figure 5B). The replacement sulfides typically surround and occur outboard of the stringer zone, which were formed by widespread hydrothermal flow surrounding and originating from the stringer veins. In addition, in ore cluster No. I, the hanging wall of this orebody, lacks mineralization and has steep contact with the orebody. A commonly thin layered carbonaceous-sulfidic chert characterized by an exhalative-sedimentary structure was observed on top of the stratiform sulfide lenses [9].

Ore cluster No. II consists of 37 orebodies occurs mainly on the top of second volcanic-sedimentary cycle of the Carboniferous (Figures 3 and 4). Most sulfide orebodies occur as stratoid and lenticular, paralleling to the host volcanic rocks. All orebodies of cluster No. II, expect for the $\mathrm{II}_{1}, \mathrm{II}_{2}, \mathrm{II}_{4}$ and $\mathrm{II}_{5}$ orebody, are small in size. The largest orebody No. $\mathrm{II}_{1}$ of ore cluster No. II is $260 \mathrm{~m}$ in length, 40 to $215 \mathrm{~m}$ in width with an average of $124 \mathrm{~m}$ and 1.8 to $16.3 \mathrm{~m}$ in thickness with an average of $6 \mathrm{~m}$ and contains 34,900 $\mathrm{t} \mathrm{Pb}$ at 7.3\%, 24,300 $\mathrm{t} \mathrm{Zn}$ at 5.1\% and $119.87 \mathrm{t} \mathrm{Ag}$ at 250.3 g/t [41,46]. The stringer and disseminated sulfides with low $\mathrm{Zn}-\mathrm{Pb}$ and high $\mathrm{Fe}-\mathrm{Cu}$ grade, appear locally beneath 
the semi-horizontal stratiform sulfides. It is common that the content of the $\mathrm{Pb}, \mathrm{Zn}$ and $\mathrm{Ag}$ in the lenses are high with an upward increase trend, yet the $\mathrm{Cu}$ content is mostly below the cutoff grade $(\sim 0.5 \%)$ displaying a downward progressive increase. A laminated carbonaceous chert, similar to the ore cluster No. I, is present locally on top of the sulfide lenses [8]. In addition, compared with the ore cluster No. I, the pyrite-dominant ores are much less common in the ore cluster No. II.

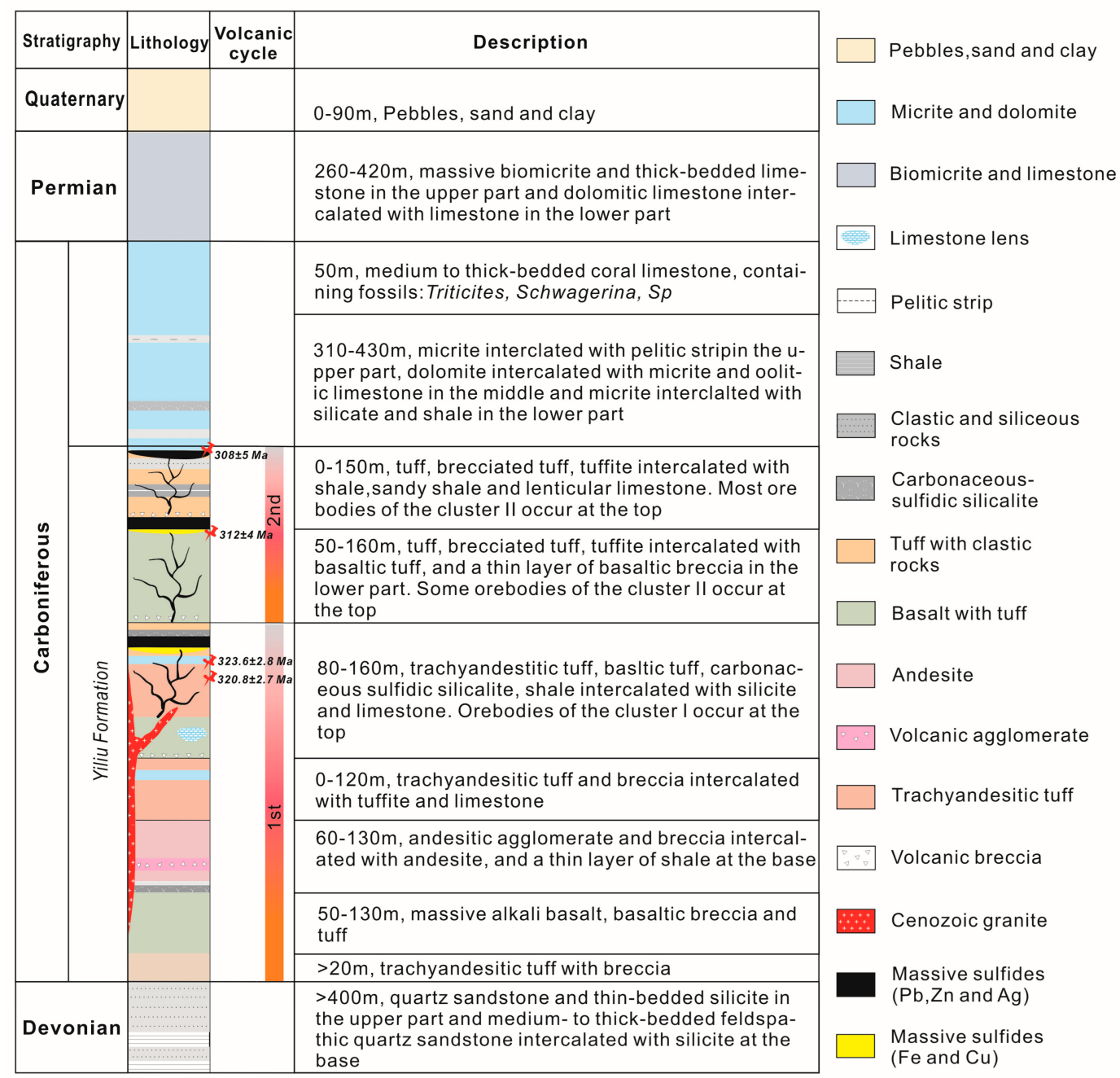

Figure 4. Lithostratigraphic column of the Laochang deposit. Note that the Carboniferous volcanic-sedimentary cycles comprise eight lithologic layers that formed during two volcanic cycles. (modified from Mo et al. [13] and Ye et al. [42]).

\subsection{Hydrothermal Alteration}

Widespread sericite-quartz-pyrite hydrothermal alteration were observed in the immediate footwall of the sulfide lenses [11]. The andesitic and basaltic tuff-dominant footwall rocks contain abundant fine-grained sericite, quartz and pyrite, whereas fine-grained sericite, quartz and pyrite are extremely rare in stringer and disseminated sulfide zones. Sericite is the most common alteration mineral. The chloritization in the footwall underneath the stratiform ore is generally weak with slight increase downward. There is no alteration in the hanging wall, which suggest that ore-forming hydrothermal activity occurred prior to the deposition of the hanging wall sequence.

In addition, low-grade metamorphic alteration in region, primarily for epidote, chlorite, serpentine, albite and calcite, has widespread influence on the Carboniferous intermediate-mafic volcanic rocks. 


\subsection{Ore Texture and Paragenesis}

Primary sulfide minerals include pyrite, sphalerite, galena and chalcopyrite (Figure 5A,C-E), with minor arsenopyrite, pyrrhotite and tetrahedrite. Gangue minerals include quartz, calcite, and minor sericite and chlorite [11]. The presence of abundant gypsum, cerussite and covellite near the surface is interpreted as secondary.

Mineralization dominantly occurs in banded ores (Figure 5A), vein (Figure 5B,D), laminated ores (Figure 5C) and massive ores (Figure 5E,F-I).
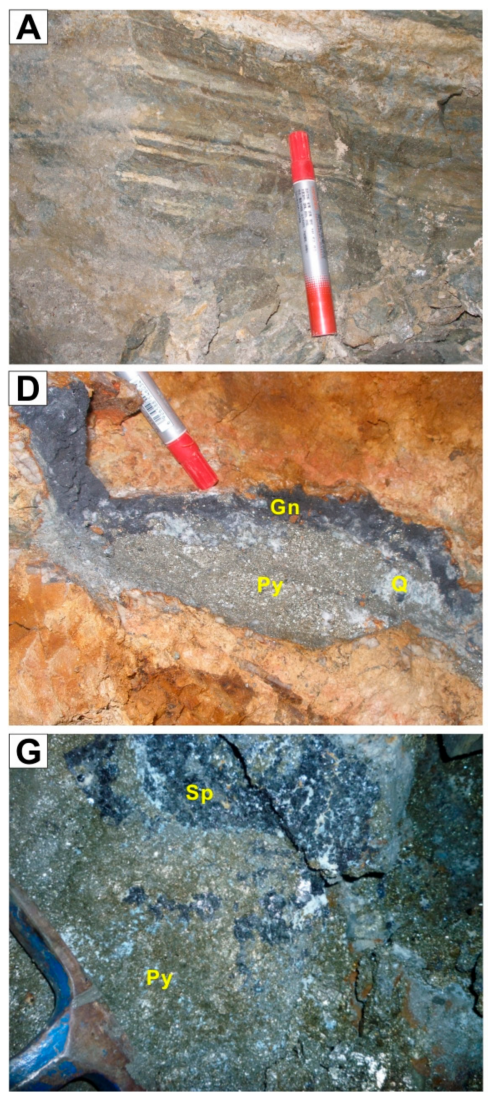
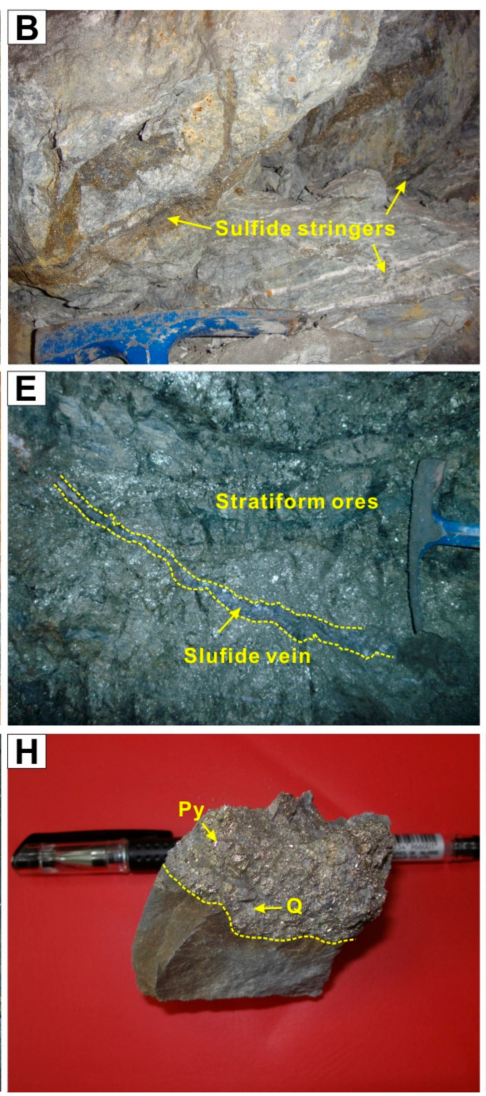

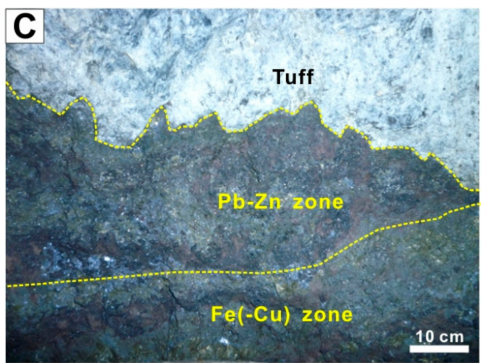

F
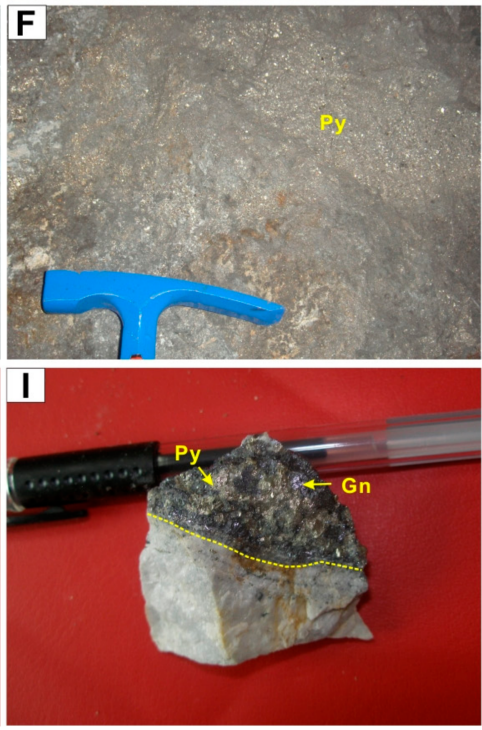

Figure 5. Photographs showing occurrences and texture of the stratabound ores at Laochang deposit. (A) Banded sulfide ore in $1650 \mathrm{~m}$ mining tunnel. (B) Tuff in 1700 mining tunnel crosscuts by vein and veinlet sulfide ore. (C) The metal zonation from top to bottom: $\mathrm{Pb}-\mathrm{Zn}$ ore to $\mathrm{Fe}-(\mathrm{Cu})$ ore from stratabound ores 1700 level. (D) Pyrite-sphalerite-galena vein filling in the fracture of tuff in $1650 \mathrm{~m}$ mining tunnel. (E) Galena-calcite vein crosscuts the stratiform ore in 1700 mining tunnel. (F) Massive coarse-pyrite ore in 1700 mining tunnel. (G) Massive sulfide ore composed of pyrite, sphalerite and minor chalcopyrite. $(\mathbf{H})$ The clear contact boundaries between the tuff and massive sulfide ore from 1650 mining tunnel. (I) The clear contact boundaries between the dolomite and massive sulfide ore in 1750 mining tunnel. Mineral abbreviations: $\mathrm{Q}=$ quartz, $\mathrm{Py}=$ pyrite, $\mathrm{Sp}=$ sphalerite, $\mathrm{Gn}=$ galena.

The principal ore textures are euhedral-subhedral granular, colloform, veinlet-vein filling, cataclastic texture and metasomatic relict. Pyrite is the predominant mineral of this deposit, which usually occurs as medium-coarse grain euhedral aggregates (Figure 5G-I). It also occurs in metasomatic relict (Figure 6A,B,D-F), colloform masses with recrystallized texture (Figure 6A,B) and cataclastic texture (Figure $6 \mathrm{H}$ ). Galena is the main carrier mineral of Ag, e.g., Ag content of galena from ore cluster No. II exceed $6900 \mathrm{ppm}$ by electron microprobe analysis [43]. They are euhedral-subhedral granular and vein, which fill in the edge of pyrite (Figure 6G), sphalerite or dissolution and replacement the euhedral pyrite (Figure 6D-F). In addition, independent Ag minerals, such as argentite wrapped in the galena, are observed [11]. Sphalerite is characteristically fine-grained, 
euhedral-subhedral granular $(0.02-10 \mathrm{~mm})$, which is replaced by galena (Figure $6 \mathrm{D})$ or replaces galena and pyrite (Figure 6A,B,F). The chalcopyrite replaces pyrite (Figure 6B) or fills in fracture of pyrite (Figure 6F). Arsenopyrite, pyrrhotite and tetrahedrite are mainly fine-grained anhedral and intergrow with other sulfides (e.g., pyrite, sphalerite and galena) [11,47].

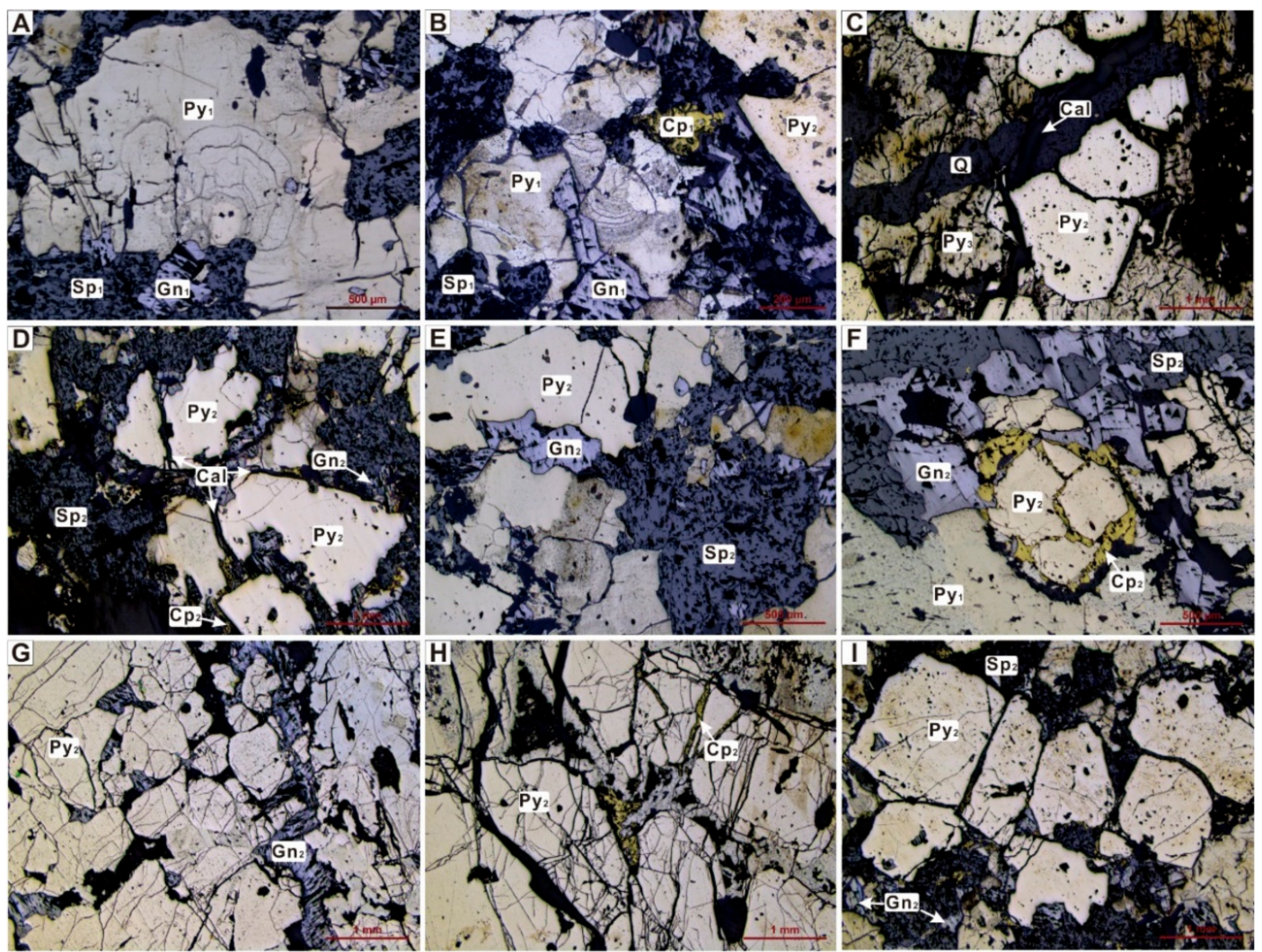

Figure 6. Mineral assemblages and textures of the stratabound ores. (A) Colloform pyrite replaced by sphalerite and galena. (B) Colloform pyrite replaced by sphalerite, chalcopyrite and galena. (C) Euhedral coarse grain pyrite crosscuts by quartz and calcite. (D) Euhedral pyrite replaced by sphalerite and galena, and chalcopyrite fills the fractures of pyrite. (E) galena and sphalerite replaced by pyrite. (F) Chalcopyrite filling in fracture of pyrite. (G) Coarse-grain pyrite crosscut by galena vein. (H) Chalcopyrite veinlets filling cracks in subhedral pyrite. (I) Interstitial filling of galena and sphalerite in subhedral pyrite. All microphotographs were taken under reflected plane-polarized light. Mineral abbreviations: $\mathrm{Cal}=$ calcite, $\mathrm{Py}=$ pyrite, $\mathrm{Sp}=$ sphalerite, $\mathrm{Gn}=$ galena, $\mathrm{Cp}=$ chalcopyrite, Cal = calcite, $\mathrm{Q}=$ quartz.

Based on field and microscope observation of crosscutting relationships, together with previously published geological data [8], the hydrothermal mineralization process of Laochang deposit can be divided into four stages (Figure 7), as follows: The hydrothermal stages I, II, III and IV. Abundant colloform pyrite ( $\left.\mathrm{Py}_{1}\right)$ was observed in hydrothermal stage I (Figure 6A,B). Hydrothermal stage II contains coarse-cubic pyrite $\left(\mathrm{Py}_{2}\right)$, black sphalerite $\left(\mathrm{Sp}_{1}\right)$, galena $\left(\mathrm{Gn}_{1}\right)$ and minor chalcopyrite $\left(\mathrm{Cp}_{1}\right)$ and quartz (Figure 6A-I). Stage III is represented by minor auhedral pyrite $\left(\mathrm{Py}_{3}\right)$, sphalerite $\left(\mathrm{Sp}_{2}\right)$, galena $\left(\mathrm{Gn}_{2}\right)$, chalcopyrite $\left(\mathrm{Cp}_{2}\right)$, quartz and minor arsenopyrite, pyrrhotite and tetrahedrite (Figure 6C,F,H). In stage IV, calcite filled in the fracture of galena and pyrite (Figure 6D) and quartz (Figure 6C). 


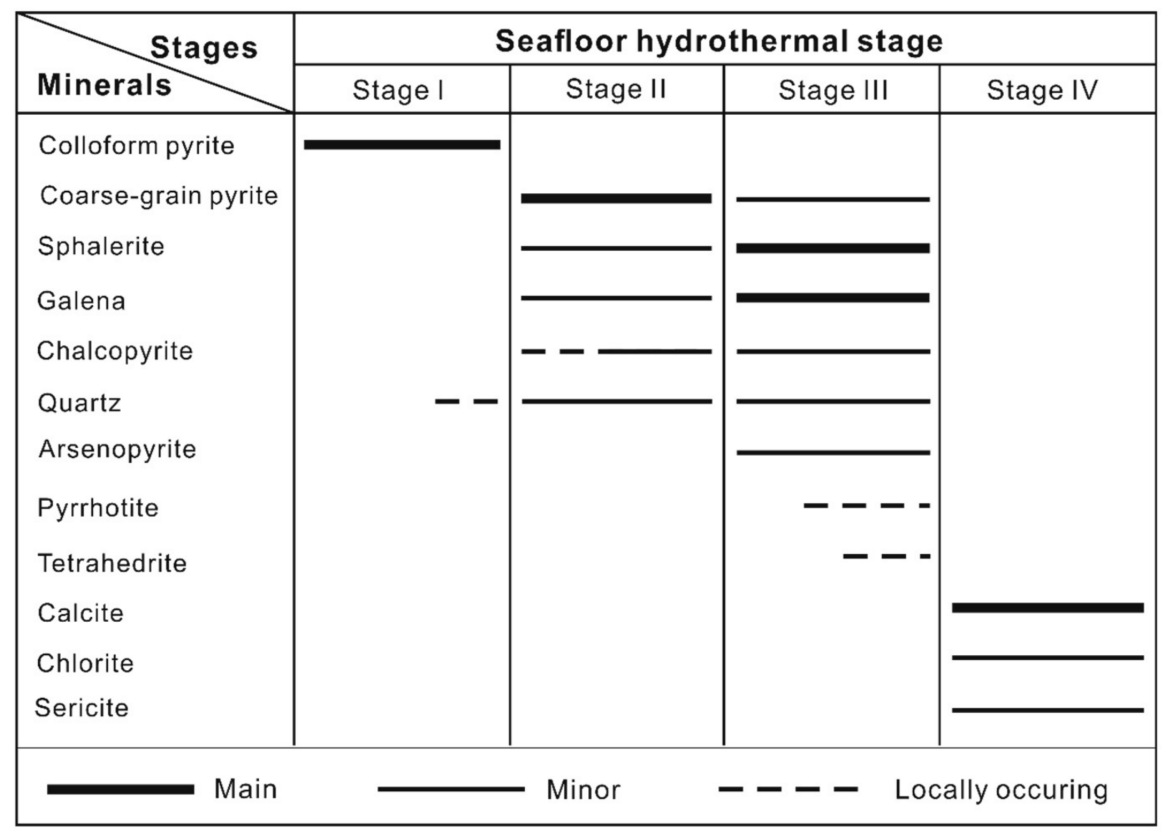

Figure 7. Mineral paragenesis in the Laochang Ag- $\mathrm{Pb}-\mathrm{Zn}-\mathrm{Cu}$ deposit.

\section{Sample and Analytical Methods}

The volcanic rock hosting the stratabound $\mathrm{Ag}-\mathrm{Pb}-\mathrm{Zn}-\mathrm{Cu}$ collected for zircon $\mathrm{U}-\mathrm{Pb}$ dating were collected under the upper orebodies layers (1840 m mining tunnel). The basalt samples used for $\mathrm{Pb}$ isotope analysis were collected from the mining adit at 1650,1725, and $1840 \mathrm{~m}$. The stratabound ores used for sulfide separation were collected from the mining adit at $1650 \mathrm{~m}$ and $1700 \mathrm{~m}$, respectively. Representative sulfide samples were crushed to $40-80$ mesh, and sphalerite, pyrite, and galena were handpicked under a binocular microscope for $\mathrm{Pb}$ isotope analysis. In addition, sphalerite from stratabound ores were used for trace element analysis.

Zircon grains for geochronology were separated by conventional heavy liquid and magnetic techniques, then handpicked under a binocular microscope, and mounted in epoxy. The mount was polished to expose the interior of the grains. The grains were photographed using transmitted and reflected light, and following gold coating, cathodoluminescence (CL) images were obtained on a scanning electron microscope (SEM) in order to select the initial analytical sites. U-Pb isotopic ratios were measured on the Sensitive High-Resolution Ion Microprobe (SHRIMP II) at the Beijing SHRIMP Center, Chinese Academy of Geological Sciences, Beijing following procedures outlined in Williams [47]. The intensity of the primary $\mathrm{O}^{2-}$ ion beam was $4-5 \mathrm{nA}$ and primary beam size was $30 \mu \mathrm{m}$. Each analytical site was rastered for 2-3 min prior to analysis to remove any common $\mathrm{Pb}$ on the surface. Five scans through nine mass stations were made for each analysis. Standards used were SL13, with U content of $238 \mathrm{ppm}$, and TEMORA 1, with a ${ }^{206} \mathrm{~Pb} /{ }^{238} \mathrm{U}$ age of $417 \mathrm{Ma}[47,48]$, provided by the Australian National University. Data processing was carried out using the SQUID and ISOPLOT programs [49], applying the ${ }^{204} \mathrm{~Pb}$ correction based on the measured values. BR266 (with an age of $559 \mathrm{Ma}$ and $\mathrm{U}$ content of $\sim 903 \mathrm{ppm}$ ) and TEMORA (417 Ma, with variable U contents) zircon fragments [48], were used as the calibration standards. Uncertainties on individual analyses are based mainly on the counting statistics and are quoted at the $1 \delta$ level, whereas uncertainties on weighted mean ages at $95 \%$ confidence level $(2 \delta)$.

For whole-rock analyses, samples were crushed to 200-mesh using an agate mill. Abundances of major elements were determined using an X-ray fluorescence spectrometer (XRF) on glass disks at the Institute of Geochemistry, Chinese Academy of Sciences (IGCAS), following analytical procedures described by Goto and Tatsumi [50,51]. A pre-ignition was used to determine the loss on ignition (LOI) prior to major element analyses. Analytical uncertainties for the majority of major elements analyzed 
were estimated at less than 1\% from repeatedly analyzed USGS standards BHVO-2, MRG-1 (basalt) and W-2 (diabase). The measured values of international standards are in satisfactory agreement with the recommended values. Whole-rock trace element data were obtained by ELAN DRC-e inductively coupled plasma-mass spectrometry (ICP-MS) (PerkinElmer, Québec, QC, Canada) at the IGCAS. The powders ( $\sim 50 \mathrm{mg}$ ) were dissolved in distilled $\mathrm{HF}_{-} \mathrm{HNO}_{3}$ in Savillex screw top Telfon vials at $150{ }^{\circ} \mathrm{C}$ for four days. More details for the ICP-MS analytical procedures could see Liu et al. [52].

Trace element analysis of sphalerite was carried out on a Finngian MAT ICP-MS (Finnigan MAT, Bremen, Germany) at the National Geological Analytical and Testing Center, Chinese Academy of Geological Sciences, Beijing, using the method of Qi et al. [53] for sample preparation. About $50 \mathrm{mg}$ of powdered sample was dissolved by $1 \mathrm{~mL}$ of $\mathrm{HF}$ and $1 \mathrm{~mL}$ of $\mathrm{HNO}_{3}$ in a PTFE bomb; then the sealed bombs were heated to $190^{\circ} \mathrm{C}$ in an electric oven for about $36 \mathrm{~h}$. After cooling, the bombs were placed on a hot plate to evaporate to dryness. $500 \mathrm{ng}$ of Rh was added as an internal standard, and then $2 \mathrm{~mL}$ of $\mathrm{HNO}_{3}$ and $4 \mathrm{~mL}$ of ultrapure water were added. The bomb was again sealed and heated to $140{ }^{\circ} \mathrm{C}$ for about $5 \mathrm{~h}$ in an electric oven to dissolve the residue. After cooling, the final dilute factor is about 3000 for ICP-MS measurements. GSR-5 was used as the external standard, with an analytical precision of better than $10 \%$. Minimum LOD were usually $1 \mathrm{ppm}$ for the trace elements (Fe, $\mathrm{Mn}, \mathrm{Cu}$ and $\mathrm{Cd}$ ) and $0.1 \mathrm{ppm}$ for In and $\mathrm{Ag}$. In addition, LOD of the trace elements (Co, $\mathrm{Ni}, \mathrm{Ga}, \mathrm{Ge}, \mathrm{Sn}, \mathrm{Sb}, \mathrm{Pb}$ and $\mathrm{Bi}$ ) better than 0.01 ppm analyzed by ICP-MS.

$\mathrm{Pb}$ isotope composition analysis was carried out using the GV Isoprobe-T thermal ionization mass spectrometer (TIMS) at the Analytical Laboratory Beijing Research Institute of Uranium Geology (ALBRIUG). The analytical procedure involves dissolution of the sample using $\mathrm{HF}$ and $\mathrm{HClO}_{4}$ in a crucible, followed by treatment with a basic anion exchange resin to purify the $\mathrm{Pb}$. The analytical results for the standard NBS-981 are ${ }^{206} \mathrm{~Pb} /{ }^{204} \mathrm{~Pb}=16.937 \pm 0.002(2 \delta),{ }^{207} \mathrm{~Pb} /{ }^{204} \mathrm{~Pb}=15.457 \pm$ $0.002(2 \delta)$, and ${ }^{208} \mathrm{~Pb} /{ }^{204} \mathrm{~Pb}=36.611 \pm 0.004(2 \delta)$. Detailed analytical procedures are described by Belshaw et al. [54].

\section{Results}

\subsection{Major and Trace Elements of Volcanic Rocks}

Major and trace element data for basalts and basaltic tuff in this study are given in Table 1. The collected samples in this study exhibit slightly higher LOI $(>1.75 \%)$, suggesting that these rocks might have undergone low-grade metamorphism during post-magmatic events [10,11]. Thus, this study mainly focuses on high field strength elements (HFSEs), rare earth elements (REEs), and transitional elements (e.g., V and Sc) for rock classification and petrogenetic discussion of the Laochang samples. All the whole-rock major element data used in the following discussion are normalized to an anhydrous basis. The Laochang basalts and basaltic tuff in this study plot in or near the fields of alkali basalt series based on the $\mathrm{Zr} / \mathrm{TiO}_{2}$ vs. $\mathrm{Nb} / \mathrm{Y}$ diagram (Figure 8). 
Table 1. Bulk rock composition of major (wt \%) and trace elements (ppm) of Laochang basalt and basaltic tuff.

\begin{tabular}{|c|c|c|c|c|c|c|c|c|c|c|c|c|c|}
\hline \multirow{2}{*}{$\begin{array}{c}\text { Rock Type } \\
\text { Sample }\end{array}$} & \multicolumn{8}{|c|}{ Basalt } & \multicolumn{5}{|c|}{ Basaltic Tuff } \\
\hline & 06LC54 & 06LC79 & $1650-31$ & $1650-34$ & $1725-11$ & $1725-21$ & LC1650-7 & LC1840-51 & LC09-29 & ZK09-41 & ZK09-24 & ZK09-36 & ZK09-44 \\
\hline $\mathrm{SiO}_{2}$ & 44.01 & 43.38 & 44.51 & 45.20 & 46.67 & 45.39 & 45.65 & 48.97 & 48.20 & 47.69 & 48.34 & 46.76 & 48.06 \\
\hline $\mathrm{Al}_{2} \mathrm{O}_{3}$ & 12.76 & 12.24 & 12.97 & 11.99 & 13.81 & 13.00 & 12.33 & 13.98 & 12.86 & 15.26 & 18.06 & 15.31 & 17.22 \\
\hline $\mathrm{FeO}$ (Total) & 15.14 & 15.54 & 12.12 & 11.23 & 10.40 & 11.39 & 15.46 & 11.9 & 12.48 & 12.21 & 10.46 & 11.75 & 11.97 \\
\hline $\mathrm{MgO}$ & 9.70 & 9.86 & 10.46 & 13.01 & 9.73 & 10.12 & 10.39 & 8.09 & 1.77 & 2.56 & 2.00 & 2.29 & 1.75 \\
\hline $\mathrm{CaO}$ & 8.53 & 8.12 & 8.57 & 9.69 & 7.55 & 8.86 & 8.25 & 8.56 & 14.22 & 12.35 & 9.34 & 13.97 & 8.85 \\
\hline $\mathrm{Na}_{2} \mathrm{O}$ & 1.59 & 2.54 & 0.65 & 0.28 & 1.58 & 1.45 & 1.12 & 0.9 & 2.15 & 3.07 & 3.78 & 3.08 & 3.54 \\
\hline $\mathrm{K}_{2} \mathrm{O}$ & 3.17 & 3.15 & 4.88 & 4.83 & 5.58 & 5.21 & 4.19 & 3.93 & 3.57 & 2.67 & 2.68 & 2.33 & 3.68 \\
\hline $\mathrm{MnO}$ & 0.17 & 0.15 & 0.14 & 0.13 & 0.12 & 0.11 & 0.14 & 0.15 & 0.2 & 0.22 & 0.16 & 0.24 & 0.13 \\
\hline $\mathrm{P}_{2} \mathrm{O}_{5}$ & 0.77 & 0.58 & 1.40 & 0.85 & 1.29 & 0.71 & 0.12 & 0.17 & 1.03 & 1.37 & 1.46 & 1.06 & 1.23 \\
\hline $\mathrm{TiO}_{2}$ & 4.16 & 4.44 & 4.30 & 2.79 & 3.26 & 3.75 & 2.35 & 3.35 & 3.52 & 2.6 & 3.72 & 3.21 & 3.57 \\
\hline Total & 100 & 100 & 100 & 100 & 100 & 100 & 100 & 100 & 100 & 100 & 100 & 100 & 100 \\
\hline LOI & 13.38 & 10.09 & 1.75 & 8.80 & 7.81 & 6.36 & 6.29 & 2.92 & 15.17 & 11.69 & 9.90 & 15.91 & 8.26 \\
\hline $\mathrm{Sc}$ & 29.17 & 31.68 & 26.42 & 21.28 & 23.52 & 22.62 & 17.10 & 23.40 & 17.60 & 10.30 & 17.30 & 12.30 & 15.80 \\
\hline $\mathrm{V}$ & 388 & 390 & 334 & 252 & 344 & 242 & 251 & 281 & 204 & 149 & 233 & 209 & 235 \\
\hline $\mathrm{Rb}$ & 102.7 & 100.7 & 419.5 & 244.4 & 330.4 & 188.3 & 358.0 & 222.0 & 104.0 & 50.9 & 57.6 & 44.6 & 78.1 \\
\hline $\mathrm{Ba}$ & 123.5 & 104.3 & 136.2 & 128.4 & 197.3 & 103.6 & 799 & 362 & 267 & 1120 & 427 & 301 & 262 \\
\hline Th & 3.68 & 4.02 & 6.72 & 6.06 & 7.37 & 6.65 & 9.33 & 4.95 & 5.57 & 6.02 & 8.06 & 6.32 & 7.68 \\
\hline $\mathrm{U}$ & 0.77 & 1.11 & 1.47 & 2.16 & 2.82 & 1.57 & 1.54 & 3.02 & 9.19 & 1.49 & 1.54 & 1.14 & 0.95 \\
\hline $\mathrm{Nb}$ & 40.72 & 43.78 & 73.96 & 55.51 & 74.21 & 70.62 & 105.00 & 64.70 & 56.10 & 65.40 & 85.60 & 68.20 & 81.80 \\
\hline $\mathrm{Ta}$ & 2.36 & 2.51 & 3.96 & 2.89 & 3.86 & 3.72 & 6.57 & 4.08 & 3.39 & 4.27 & 5.69 & 4.44 & 5.43 \\
\hline $\mathrm{La}$ & 28.32 & 30.64 & 64.37 & 46.28 & 63.61 & 53.82 & 74 & 50.9 & 71.9 & 76.3 & 73.7 & 60.9 & 71.9 \\
\hline $\mathrm{Ce}$ & 63.71 & 65.98 & 133.70 & 90.95 & 133.40 & 118.80 & 163.00 & 109.00 & 126.00 & 103.00 & 162.00 & 116.00 & 152.00 \\
\hline $\mathrm{Sr}$ & 413.4 & 432.5 & 398.9 & 288.0 & 354.4 & 91.4 & 182.0 & 105.0 & 132.0 & 439.0 & 342.0 & 453.0 & 371.0 \\
\hline $\mathrm{Nd}$ & 34.43 & 34.14 & 66.38 & 41.80 & 64.16 & 57.67 & 69.70 & 59.90 & 59.60 & 75.00 & 74.50 & 55.50 & 68.10 \\
\hline Sm & 7.63 & 7.07 & 12.80 & 8.01 & 12.32 & 10.60 & 13.00 & 11.60 & 11.40 & 14.00 & 15.40 & 10.90 & 13.70 \\
\hline $\mathrm{Zr}$ & 231 & 254 & 305 & 199 & 288 & 275 & 356 & 220 & 247 & 295 & 378 & 296 & 360 \\
\hline Hf & 5.09 & 5.44 & 5.79 & 3.81 & 5.42 & 5.1 & 7.29 & 5.06 & 5.20 & 5.88 & 8.04 & 7.26 & 7.86 \\
\hline $\mathrm{Eu}$ & 3.01 & 2.41 & 4.37 & 2.38 & 4.12 & 3.63 & 4.51 & 4.39 & 6.23 & 4.57 & 4.79 & 3.62 & 4.27 \\
\hline $\mathrm{Gd}$ & 8.25 & 6.84 & 11.13 & 7.49 & 10.8 & 9.44 & 11.35 & 10.69 & 10.23 & 13.48 & 13.22 & 9.80 & 12.01 \\
\hline Dy & 6.50 & 5.13 & 7.26 & 5.03 & 6.73 & 5.99 & 7.31 & 6.69 & 7.19 & 8.89 & 9.99 & 7.37 & 8.94 \\
\hline Y & 29.30 & 23.56 & 30.29 & 22.95 & 28.42 & 25.32 & 32.83 & 29.72 & 37.23 & 43.67 & 45.71 & 31.65 & 40.34 \\
\hline $\mathrm{Yb}$ & 2.29 & 1.88 & 2.11 & 1.65 & 1.95 & 1.84 & 2.3 & 1.87 & 2.25 & 3.18 & 3.54 & 2.35 & 3.25 \\
\hline
\end{tabular}


Table 1. Cont

\begin{tabular}{|c|c|c|c|c|c|c|c|c|c|c|c|c|c|}
\hline \multirow{2}{*}{$\begin{array}{c}\text { Rock Type } \\
\text { Sample }\end{array}$} & \multicolumn{8}{|c|}{ Basalt } & \multicolumn{5}{|c|}{ Basaltic Tuff } \\
\hline & 06LC54 & 06LC79 & $1650-31$ & $1650-34$ & $1725-11$ & $1725-21$ & LC1650-7 & LC1840-51 & LC09-29 & ZK09-41 & ZK09-24 & ZK09-36 & ZK09-44 \\
\hline $\mathrm{Lu}$ & 0.33 & 0.26 & 0.29 & 0.23 & 0.27 & 0.25 & 0.33 & 0.27 & 0.31 & 0.44 & 0.51 & 0.33 & 0.46 \\
\hline$(\mathrm{La} / \mathrm{Sm})_{\mathrm{N}}$ & 2.40 & 2.80 & 3.25 & 3.73 & 3.34 & 3.28 & 3.68 & 2.84 & 4.08 & 3.52 & 3.09 & 3.61 & 3.39 \\
\hline$(\mathrm{Gd} / \mathrm{Yb})_{\mathrm{N}}$ & 2.98 & 3.01 & 4.36 & 3.75 & 4.58 & 4.24 & 4.08 & 4.73 & 3.76 & 3.51 & 3.09 & 3.45 & 3.06 \\
\hline$(\mathrm{La} / \mathrm{Yb})_{\mathrm{N}}$ & 8.87 & 11.70 & 21.89 & 20.13 & 23.41 & 20.99 & 23.09 & 19.53 & 22.93 & 17.22 & 14.94 & 18.60 & 15.88 \\
\hline
\end{tabular}




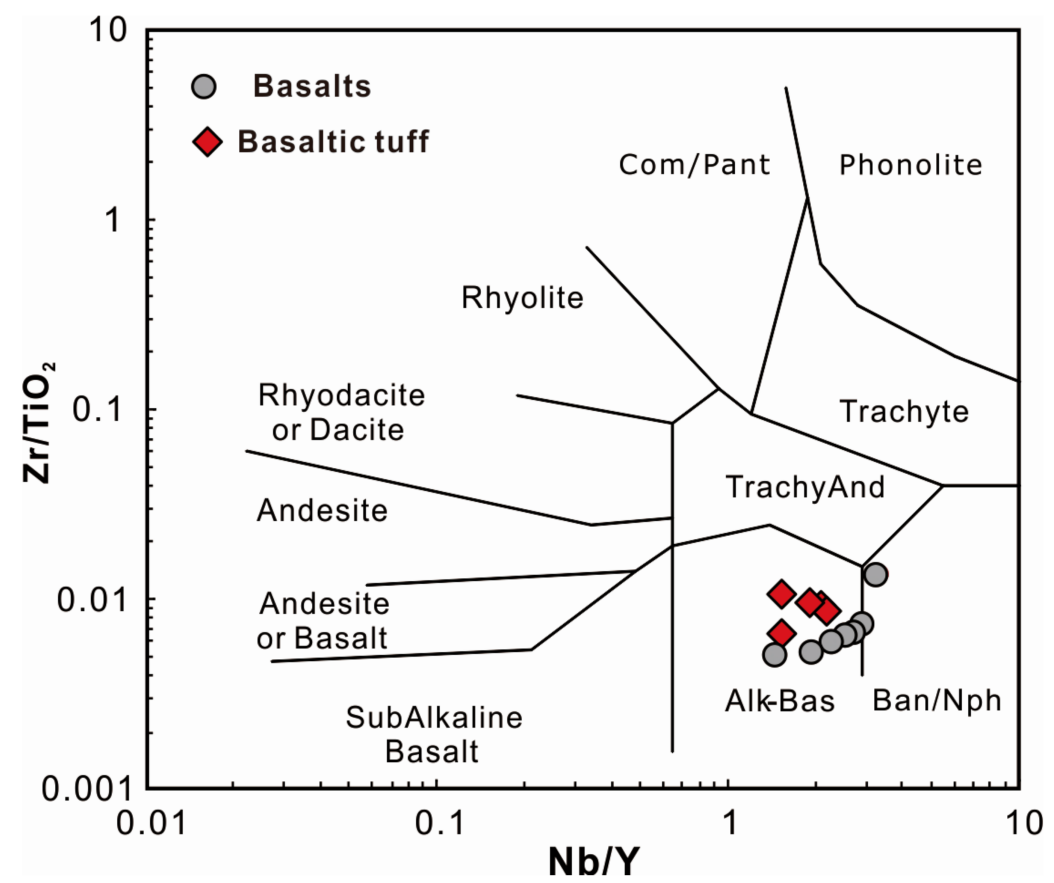

Figure 8. Bulk-rock compositions of the Laochang volcanic rocks in a $\mathrm{Zr} / \mathrm{Ti}$ versus $\mathrm{Nb} / \mathrm{Y}$.

The Laochang basalt samples have $\mathrm{SiO}_{2}$ of $43.38-48.97 \%, \mathrm{MgO}$ of $8.09-13.01 \%, \mathrm{CaO}$ of $7.55-9.69 \%$, $\mathrm{Al}_{2} \mathrm{O}_{3}$ of $11.99-13.98 \%, \mathrm{TiO}_{2}$ of $2.35-4.44 \%$ and $\mathrm{P}_{2} \mathrm{O}_{5}$ of $0.12-1.40 \%$. In primitive-mantle normalized trace element patterns (Figure 9A), they are characterized by enrichment of HFSEs, such as $\mathrm{Nb}$, $\mathrm{Ta}, \mathrm{Zr}$, and Hf, and most large ion lithophile elements (LILEs), such as $\mathrm{Rb}$, Th, U, and light REE, but show Ba and Sr depletion. Chondrite normalized REE patterns (Figure 9B) show weakly fractionated light rare earth element (LREE) patterns, with $(\mathrm{La} / \mathrm{Sm})_{\mathrm{N}}=2.40-4.08,(\mathrm{Gd} / \mathrm{Yb})_{\mathrm{N}}=2.98-4.73$, $(\mathrm{La} / \mathrm{Yb})_{\mathrm{N}}=8.87-23.41$.

The basaltic samples have $\mathrm{SiO}_{2}$ of $46.76-48.34 \%, \mathrm{MgO}$ of $1.75-2.65 \%$, CaO of $8.85-14.22 \%$, $\mathrm{Al}_{2} \mathrm{O}_{3}$ of $12.86-18.06 \%, \mathrm{TiO}_{2}$ of $2.60-3.72 \%$ and $\mathrm{P}_{2} \mathrm{O}_{5}$ of $1.03-1.46 \%$. In primitive-mantle normalized trace element patterns and chondrite normalized REE patterns (Figure 9A,B), it has geochemical compositions similar to those of basalt from the Laochang.

Additionally, the trace elements and REE patterns of the basalt and basaltic tuff are almost identical, resembling those of the OIB reservoir formed by oceanic hotspot volcanism $[55,56]$.
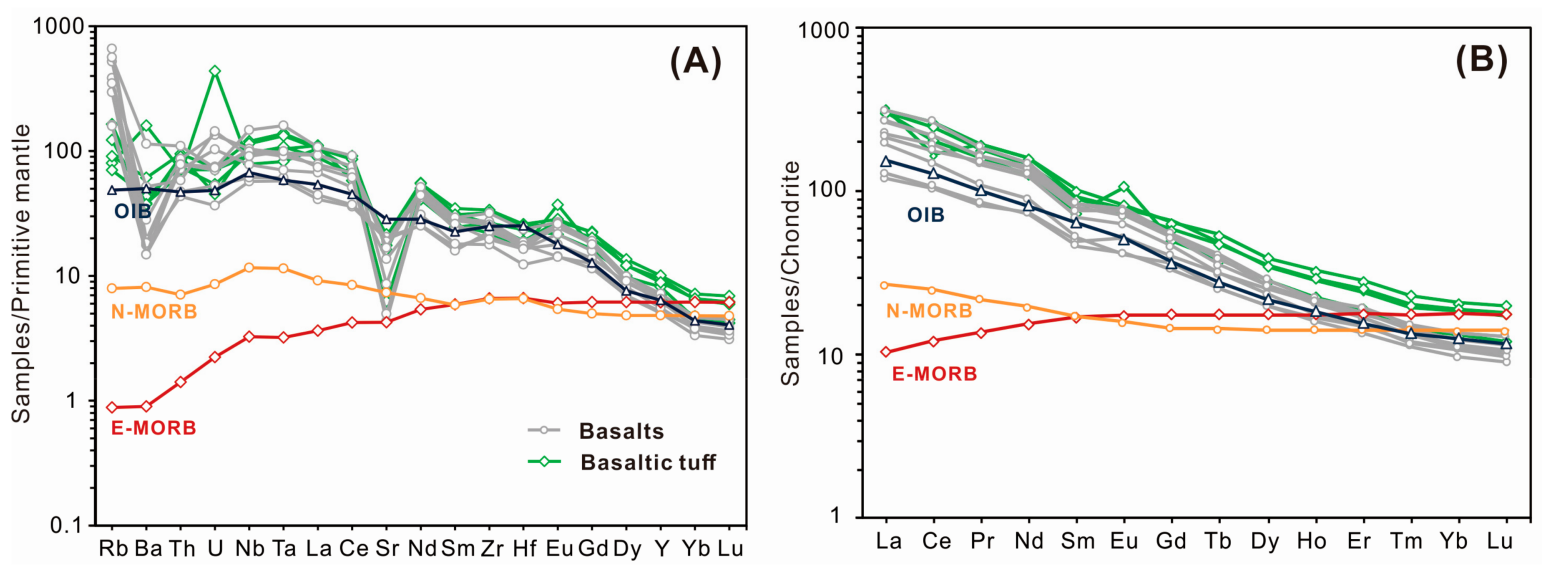

Figure 9. Primitive mantle-normalized trace element diagrams. (A) and chrondrite-normalized rare earth element (REE) patterns (B) for the Laochang basalt and basaltic tuff. The primitive mantle and chrondrite values are from Sun and McDonough [57]. 


\subsection{Zircon $\mathrm{U}-\mathrm{Pb}$ Geochronology}

Data for U-Pb zircon chronological analyses are given in Table 2. Zircon grains from a basaltic tuff samples (LC09-102) display 74.6-1950 ppm Th and 58.63-557.77 ppm U, with Th/U ratios ranging from 1.29 to 3.52. Zircons from this sample show weak oscillatory zoning (Figure 10). Nine analyses are concordant. Our $\mathrm{U}-\mathrm{Pb}$ zircon dating yielded the ${ }^{206} \mathrm{~Pb} /{ }^{238} \mathrm{U}$ concordia age from $303 \mathrm{Ma}$ to $316 \mathrm{Ma}$ with a weighted mean ${ }^{206} \mathrm{~Pb} /{ }^{238} \mathrm{U}$ age of $312 \pm 4 \mathrm{Ma}(\mathrm{MSWD}=1.02)$. Three spots from three zircon cores have relatively old ${ }^{206} \mathrm{~Pb} /{ }^{238} \mathrm{U}$ age from $741 \pm 15 \mathrm{Ma}$ to $712 \pm 17 \mathrm{Ma}$, which are interpreted to be inherited components.
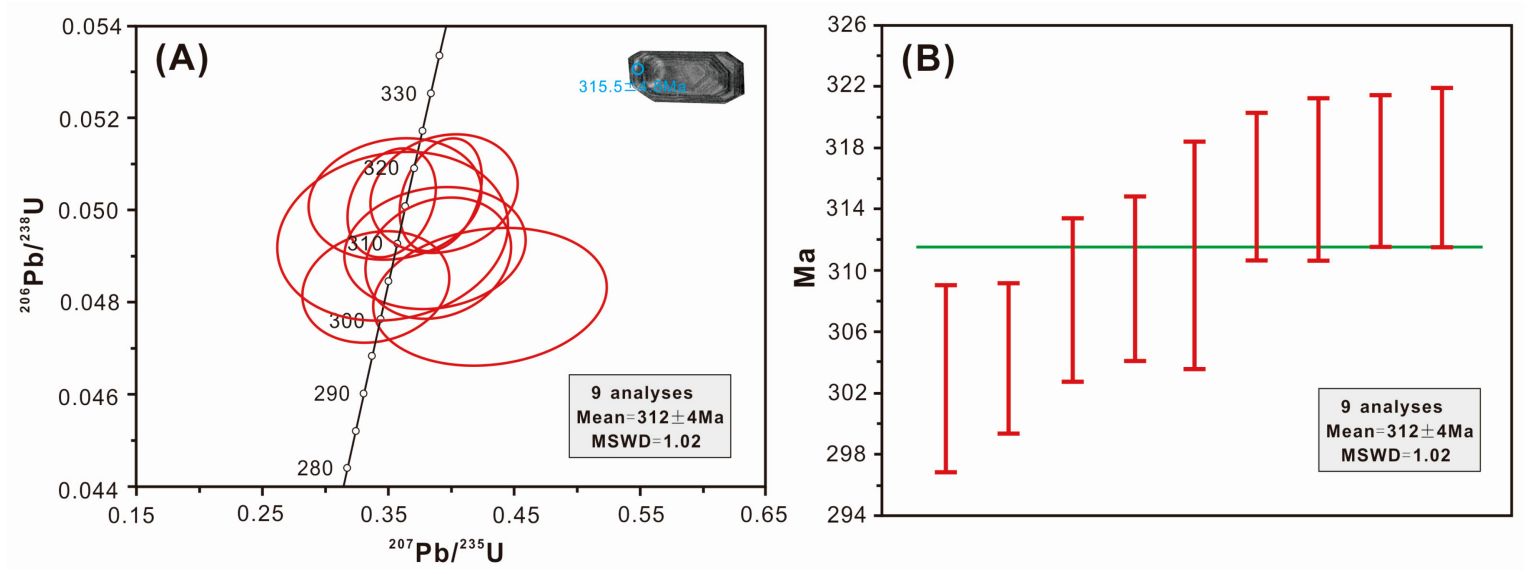

Figure 10. Zircon SIMS U-Pb Concordia diagram (A,B) for the dated volcanic rocks (LC09-102) from the Early Carboniferous Yiliu Formation in Laochang district.

\subsection{Trace Elements in Sphalerite}

The trace elements in sphalerite from stratabound ores are summarized in Table 3. The ranges in absolute concentration for selected elements are shown in Figure 11. 

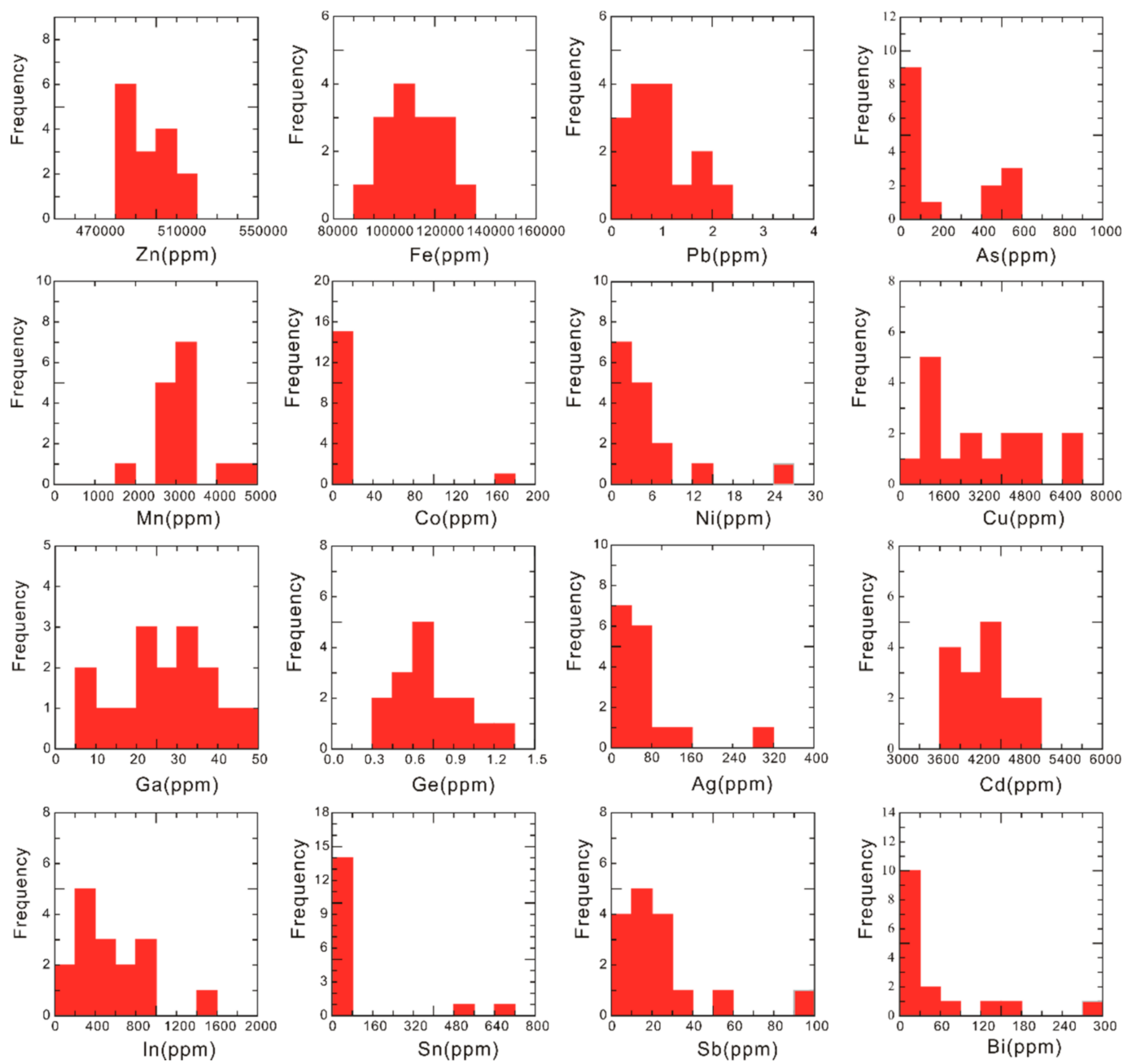

Figure 11. Histogram of trace elements for sphalerite of the stratabound Ag- $\mathrm{Pb}-\mathrm{Zn}-\mathrm{Cu}$ ores from the Laochang deposit.

The concentrations of trace elements in the various sphalerite samples are relatively homogeneous, except for $\mathrm{Cu}, \mathrm{Sn}, \mathrm{Sb}, \mathrm{Bi}$, and $\mathrm{Ag}$, which vary widely, ranging from 788 7161 ppm, 4.44 702.30 ppm, 3.85 90.19 ppm, 0.84 278.30 ppm, and 11.3 311.0 ppm, respectively. In general, sphalerite from stratabound ores has the following characteristics: (1) Enrichment of $\mathrm{Fe}, \mathrm{Cd}$ and $\mathrm{Mn}$ contents, for which the concentration ranges are 98,800 132,500 ppm (average 111,750 ppm), 3813 4993 ppm (average $4243 \mathrm{ppm}$ ), and 1971 4594 ppm (average $3133 \mathrm{ppm}$ ), respectively; (2) relative enrichment of In and Ga contents, for which the concentration ranges are 192.1 1576.0 ppm (average $521.8 \mathrm{ppm}$ ) and 8.15 45.40 ppm (average $28.10 \mathrm{ppm}$ ), respectively; (3) relatively low Co and Ni contents, with concentrations ranging from $0.17 \sim 6.53 \mathrm{ppm}$, with an average of $1.70 \mathrm{ppm}$, and 1.13 26.68 ppm, with an average of $5.50 \mathrm{ppm}$; and (4) low $\mathrm{Ge}, \mathrm{Pb}$ and As contents, with concentrations ranging from $0.41 \sim 1.30 \mathrm{ppm}, 0.07 \sim 2.30 \mathrm{ppm}$ and $34.72 \sim 589.60 \mathrm{ppm}$, with an average of $0.7 \mathrm{ppm}, 0.9 \mathrm{ppm}$ and $213.8 \mathrm{ppm}$, respectively. Collectively, sphalerite of the stratabound ores is characterized by enriched $\mathrm{Fe}, \mathrm{Mn}, \mathrm{Cd}$, In, and $\mathrm{Ga}$, and depleted $\mathrm{Co}, \mathrm{Ni}, \mathrm{Ge}$, and $\mathrm{Pb}$. Moreover, the contents of $\mathrm{Fe}, \mathrm{Mn}, \mathrm{Cd}$, In, $\mathrm{Ga}$ $\mathrm{Co}, \mathrm{Ni}, \mathrm{Ge}$, and $\mathrm{Pb}$ are relatively consistent, whereas $\mathrm{Sn}, \mathrm{Sb}, \mathrm{Cu}$, and $\mathrm{Bi}$ show a wide range. 
Table 2. SHRIMP zircon U-Pb isotopic data for basaltic tuff of the Laochang.

\begin{tabular}{|c|c|c|c|c|c|c|c|c|c|c|c|c|c|c|c|}
\hline \multirow{2}{*}{ Analysis } & \multicolumn{3}{|c|}{ Element (ppm) } & \multicolumn{6}{|c|}{ Isotopic Ratio } & \multicolumn{6}{|c|}{ Age (Ma) } \\
\hline & ${ }^{232} \mathrm{Th}$ & ${ }^{238} \mathrm{U}$ & ${ }^{232} \mathrm{Th} /{ }^{238} \mathrm{U}$ & ${ }^{207} \mathrm{~Pb} /{ }^{206} \mathrm{~Pb}$ & $\pm 1 \delta$ & ${ }^{207} \mathrm{~Pb} /{ }^{235} \mathrm{U}$ & $\pm 1 \delta$ & ${ }^{206} \mathrm{~Pb} /{ }^{238} \mathrm{U}$ & $\pm 1 \delta$ & ${ }^{206} \mathrm{~Pb} /{ }^{238} \mathrm{U}$ & $1 \delta$ & ${ }^{208} \mathrm{~Pb} /{ }^{232} \mathrm{Th}$ & 18 & ${ }^{207} \mathrm{~Pb} /{ }^{206} \mathrm{~Pb}$ & $1 \delta$ \\
\hline LC09-10-1 & 391 & 742 & 1.96 & 0.0518 & 17 & 0.35 & 17 & 0.05 & 2.4 & 311.0 & 7.4 & 307 & 13 & 278 & 390 \\
\hline LC09-10-2 & 286 & 568 & 2.05 & 0.0571 & 12 & 0.39 & 12 & 0.05 & 1.8 & 309.5 & 5.4 & 302.8 & 9.2 & 494 & 270 \\
\hline LC09-10-3 & 420 & 793 & 1.95 & 0.0511 & 11 & 0.34 & 11 & 0.05 & 1.6 & 304.3 & 4.9 & 296.7 & 7.8 & 243 & 260 \\
\hline LC09-10-4 & 558 & 1950 & 3.61 & 0.051 & 6.3 & 0.35 & 6.5 & 0.05 & 1.6 & 315.5 & 4.8 & 309.5 & 5.9 & 243 & 150 \\
\hline LC09-10-5 & 495 & 1688 & 3.52 & 0.0564 & 5.3 & 0.39 & 5.5 & 0.05 & 1.6 & 316.5 & 5.0 & 307.8 & 6.2 & 470 & 120 \\
\hline LC09-10-6 & 177 & 407 & 2.38 & 0.0649 & 14 & 0.43 & 14 & 0.05 & 2.1 & 303.0 & 6.1 & 293 & 13 & 772 & 300 \\
\hline LC09-10-7 & 72 & 90 & 1.29 & 0.058 & 18 & 0.96 & 19 & 0.12 & 3.9 & 730.0 & 27 & 655 & 53 & 523 & 400 \\
\hline LC09-10-8 & 301 & 592 & 2.03 & 0.0577 & 9.5 & 0.39 & 9.7 & 0.05 & 1.8 & 308.1 & 5.3 & 308.7 & 8.9 & 520 & 210 \\
\hline LC09-10-9 & 419 & 1209 & 2.99 & 0.0513 & 13 & 0.36 & 13 & 0.05 & 1.7 & 316.0 & 5.3 & 306.3 & 7.4 & 254 & 290 \\
\hline LC09-10-10 & 59 & 75 & 1.31 & 0.0677 & 6.9 & 1.09 & 7.3 & 0.12 & 2.5 & 712 & 17 & 708 & 34 & 858 & 140 \\
\hline LC09-10-11 & 115 & 173 & 1.56 & 0.067 & 9.8 & 1.13 & 10 & 0.12 & 2.1 & 741 & 15 & 738 & 31 & 839 & 200 \\
\hline LC09-10-12 & 359 & 769 & 2.21 & 0.0568 & 9.6 & 0.39 & 9.8 & 0.05 & 1.7 & 316.7 & 5.2 & 310.0 & 7.9 & 483 & 210 \\
\hline
\end{tabular}

Table 3. Trace elements in sphalerite from stratabound ores of Laochang deposit.

\begin{tabular}{|c|c|c|c|c|c|c|c|c|c|c|c|c|c|c|c|c|}
\hline Sample Na. & $\mathrm{Zn}$ & $\mathrm{Fe}$ & Mn & Co & $\mathrm{Ni}$ & $\mathrm{Cu}$ & $\mathrm{Ga}$ & $\mathrm{Ge}$ & As & $\mathrm{Ag}$ & $\mathrm{Cd}$ & In & Sn & $\mathrm{Sb}$ & $\mathrm{Pb}$ & Bi \\
\hline Lcs75 & 49.79 & 112,000 & 4026 & 1.57 & 6.61 & 4912 & 30.32 & 0.64 & 88.74 & 15.0 & 4250 & 633.2 & 35.79 & 8.56 & 0.37 & 0.84 \\
\hline Lcs67 & 48.96 & 110,500 & 2768 & 3.14 & 1.64 & 1079 & 24.48 & 0.86 & 34.72 & 64.1 & 4993 & 941.7 & 19.58 & 53.34 & 2.30 & 0.87 \\
\hline Lcs76 & 50.66 & 110,500 & 3258 & 4.09 & 4.36 & 7161 & 30.65 & 0.47 & 105.80 & 27.2 & 4201 & 1576.0 & 25.7 & 19.79 & 1.19 & 1.31 \\
\hline Lcc5 & 49.59 & 98,800 & 1971 & 1.49 & 12.67 & 5058 & 21.31 & 1.30 & 80.76 & 48.7 & 3859 & 696.6 & 12.21 & 30.51 & 1.69 & 2.60 \\
\hline Lcs68 & 50.57 & 132,500 & 4594 & 1.84 & 2.92 & 2765 & 45.40 & 0.64 & 90.46 & 16.4 & 4186 & 849.4 & 702.3 & 11.86 & 0.63 & 2.74 \\
\hline Lcs69 & 48.72 & 117,800 & 2785 & 1.12 & 1.43 & 2398 & 26.55 & 0.62 & 62.35 & 11.3 & 4420 & 558.2 & 13.10 & 6.97 & 0.46 & 4.78 \\
\hline Lc117 & 48.47 & 100,400 & 3154 & 2.27 & 2.17 & 1053 & 19.29 & 0.58 & 43.45 & 13.8 & 4717 & 192.1 & 12.52 & 10.08 & 0.51 & 6.21 \\
\hline Lcb5 & 48.95 & 110,800 & 2562 & 6.53 & 1.13 & 788 & 8.15 & 0.41 & 543.30 & 17.6 & 3867 & 217.4 & 4.44 & 3.85 & 0.07 & 12.28 \\
\hline Lcs73 & 51.14 & 92,550 & 3211 & 1.10 & 26.68 & 3307 & 36.90 & 1.13 & 54.93 & 67.3 & 4690 & 289.5 & 15.84 & 13.75 & 0.96 & 27.30 \\
\hline Lcc27 & 49.81 & 123,100 & 3168 & 0.17 & 4.80 & 2887 & 44.44 & 0.67 & 543.60 & 78.7 & 4303 & 502.0 & 514.4 & 25.26 & 0.40 & 39.06 \\
\hline Lcc9 & 51.58 & 112,600 & 3052 & 0.87 & 5.89 & 4129 & 30.81 & 0.99 & 46.10 & 43.7 & 4424 & 532.0 & 20.20 & 22.80 & 1.77 & 59.02 \\
\hline Lcc16 & 48.66 & 102,400 & 2977 & 0.20 & 1.28 & 1321 & 28.56 & 0.65 & 429.40 & 43.8 & 3914 & 308.8 & 21.51 & 8.60 & 0.29 & 72.71 \\
\hline Lcc 28 & 48.77 & 123,600 & 3278 & 0.93 & 2.39 & 1584 & 23.56 & 0.55 & 411.50 & 311.0 & 3874 & 353.3 & 12.49 & 22.08 & 0.92 & 131.30 \\
\hline Lcs 48 & 50.52 & 121,100 & 2820 & 0.31 & 5.26 & 6720 & 12.90 & 0.41 & 82.53 & 82.5 & 3813 & 871.3 & 50.92 & 90.19 & 1.31 & 174.80 \\
\hline Lk16 & 50.44 & 107,600 & 3377 & 0.21 & 3.05 & 1096 & 38.44 & 0.90 & 589.60 & 126.0 & 4126 & 356.1 & 32.98 & 20.27 & 0.82 & 278.30 \\
\hline Min & 48.47 & 98,800 & 1971 & 0.17 & 1.13 & 788 & 8.15 & 0.41 & 34.72 & 11.3 & 3813 & 192.1 & 4.44 & 3.85 & 0.07 & 0.84 \\
\hline Max & 51.58 & 132,500 & 4594 & 6.53 & 26.68 & 7161 & 45.40 & 1.30 & 589.60 & 311.0 & 4993 & 1576.0 & 702.30 & 90.19 & 2.30 & 278.30 \\
\hline Mean & 49.8 & 111,750 & 3133 & 1.70 & 5.50 & 3084 & 28.10 & 0.70 & 213.80 & 64.5 & 4243 & 591.8 & 99.60 & 23.20 & 0.90 & 54.30 \\
\hline S.D. & 3.11 & 34,500 & 2623 & 6.36 & 25.55 & 6373 & 37.25 & 0.89 & 554.88 & 299.7 & 1180 & 1383.9 & 697.96 & 86.34 & 2.23 & 277.46 \\
\hline
\end{tabular}

Notes: $\mathrm{Zn}$ is expressed in $\mathrm{wt} \%$ and trace element contents are expressed in ppm, and S.D. stand for standard deviation in this table. 


\section{4. $\mathrm{Pb}$ Isotopes}

Lead isotope data for the volcanic rock, granitic porphyry and sulfide samples from stratabound mineralization are listed in Table 4 . The seven volcanic samples have whole-rock ${ }^{206} \mathrm{~Pb} /{ }^{204} \mathrm{~Pb}$ ratios of 18.595 to $18.918,{ }^{207} \mathrm{~Pb} /{ }^{204} \mathrm{~Pb}$ ratios of 15.597 to 15.749 , and ${ }^{208} \mathrm{~Pb} /{ }^{204} \mathrm{~Pb}$ ratios of 38.852 to 39.112 , which are characterized by high radiogenic $\mathrm{Pb}$ isotopic composition. The lead isotope ratios of galena, pyrite, and sphalerite from stratabound ores are 18.341 to 18.915 for ${ }^{206} \mathrm{~Pb} /{ }^{204} \mathrm{~Pb}, 15.376$ to 15.770 for ${ }^{207} \mathrm{~Pb} /{ }^{204} \mathrm{~Pb}$, and 38.159 to 39.200 for ${ }^{208} \mathrm{~Pb} /{ }^{204} \mathrm{~Pb}$.

$\mathrm{Xu}$ et al. [58] and Zhao et al. [59] reported lead isotope composition of concealed granitic porphyry, which is relatively homogeneous: ${ }^{206} \mathrm{~Pb} /{ }^{204} \mathrm{~Pb}=17.988$ to $18.621,{ }^{207} \mathrm{~Pb} /{ }^{204} \mathrm{~Pb}=15.586$ to 16.663 , ${ }^{208} \mathrm{~Pb} /{ }^{204} \mathrm{~Pb}=38.246$ to 38.910 (Table 4$)$.

Table 4. Pb isotope data of rock and sulfides from the Laochang deposit.

\begin{tabular}{|c|c|c|c|c|c|c|}
\hline Sample No. & Sample Na. & Sample Location & ${ }^{206} \mathrm{~Pb} /{ }^{204} \mathrm{~Pb}$ & ${ }^{207} \mathrm{~Pb} /{ }^{204} \mathrm{~Pb}$ & ${ }^{208} \mathrm{~Pb} /{ }^{204} \mathrm{~Pb}$ & References \\
\hline E-51 & Granitic porphyry & ZK14827-998.5 m & 18.205 & 15.586 & 38.405 & \multirow{5}{*}{ Zhao et al. [59] } \\
\hline E-67 & Granitic porphyry & ZK14827-214.8 m & 18.426 & 15.601 & 38.623 & \\
\hline E-73 & Granitic porphyry & ZK14827-302.8 m & 18.564 & 15.62 & 38.774 & \\
\hline E-82 & Granitic porphyry & ZK14827-389 m & 18.621 & 15.663 & 38.910 & \\
\hline E-84 & Granitic porphyry & ZK14827-412 m & 18.283 & 15.628 & 38.524 & \\
\hline 88061 & Granitic porphyry & ZK15007-355 m & 18.561 & 15.614 & 38.695 & \multirow{3}{*}{ Xu et al. [58] } \\
\hline 88088 & Granitic porphyry & ZK15006-427 m & 17.988 & 15.652 & 38.246 & \\
\hline 88090 & Granitic porphyry & ZK15006-440 m & 18.552 & 15.661 & 38.766 & \\
\hline LC091700-27 & Pyrite & 1700 mining tunnel & 18.601 & 15.659 & 38.835 & \multirow{6}{*}{ This study } \\
\hline LC091700-41 & Pyrite & 1700 mining tunnel & 18.623 & 15.646 & 38.823 & \\
\hline LC091700-45 & Pyrite & 1700 mining tunnel & 18.657 & 15.682 & 38.935 & \\
\hline LC091700-49 & Sphalerite & 1700 mining tunnel & 18.651 & 15.643 & 38.880 & \\
\hline LC091700-53 & Sphalerite & 1700 mining tunnel & 18.449 & 15.487 & 38.423 & \\
\hline LC091700-54 & Sphalerite & 1700 mining tunnel & 18.452 & 15.528 & 38.396 & \\
\hline Lc1925-3 & Galena & & 18.736 & 15.758 & 39.09 & \multirow{4}{*}{ Ye et al. [42] } \\
\hline Lc1925-5 & Galena & & 18.700 & 15.732 & 39.100 & \\
\hline Lc1925-12 & Galena & & 18.748 & 15.77 & 39.197 & \\
\hline Lc1925-13 & Galena & & 18.716 & 15.729 & 39.087 & \\
\hline Ly017 & Galena & & 18.500 & 15.480 & 38.380 & \multirow{8}{*}{ Li et al. [8] } \\
\hline Ly020 & Galena & & 18.510 & 15.500 & 38.410 & \\
\hline Ly016 & Galena & & 18.590 & 15.600 & 38.68 & \\
\hline Lc-3G & Galena & & 18.726 & 15.761 & 39.200 & \\
\hline Lc-9G & Galena & & 18.657 & 15.700 & 38.973 & \\
\hline Lc-12G & Galena & & 18.726 & 15.762 & 39.200 & \\
\hline Lc- $4 \mathrm{P}$ & Pyrite & & 18.676 & 15.699 & 39.000 & \\
\hline Lc-9P & Pyrite & & 18.709 & 15.763 & 39.191 & \\
\hline $1700-23$ & Basalt & 1700 mining tunnel & 18.668 & 15.597 & 38.852 & \multirow{5}{*}{ This study } \\
\hline $1725-27$ & Basalt & 1725 mining tunnel & 18.595 & 15.672 & 38.867 & \\
\hline $1700-5$ & Basalt & 1700 mining tunnel & 18.619 & 15.672 & 38.905 & \\
\hline $1650-19$ & Basalt & 1650 mining tunnel & 18.612 & 15.657 & 38.901 & \\
\hline $1700-6$ & Basalt & 1700 mining tunnel & 18.751 & 15.668 & 39.112 & \\
\hline 87-B8 & Basalt & & 18.661 & 15.709 & 38.902 & \multirow{2}{*}{ Xu et al. [58] } \\
\hline 8725_1 & Volcanic rock & & 18.918 & 15.749 & 39.037 & \\
\hline
\end{tabular}

\section{Discussion}

\subsection{Age of Stratabound Mineralization}

Zircon grains from the Carboniferous volcano-sedimentary sequence (Yiliu Formation) in Laochang deposit show morphological and compositional features typical of magmatic zircons (Figure 10, Table 1). The precise SHRIMP zircon U-Pb age (312 $\pm 4 \mathrm{Ma}$ ) present here provides a tight constraint on the eruption timing of Yiliu Formation basaltic tuff in $1840 \mathrm{~m}$ mining tunnel. This age is much younger than previous studies (320.8 $\pm 2.7 \mathrm{Ma}$ by LA-ICP-MS, Deng et al. [17]; $323.6 \pm 2.8 \mathrm{Ma}$ by SHRIMP, Chen et al. [60]), which either reflect multistage magmatic eruption at Laochang or different analytical protocols used by those authors. Our field observations and drill core logging identify that the Yiliu Formation is composed of two lava-agglomerates-breccia-tuff-sedimentary basic groups. 
Thus, it is suggested that the different ages have more likely resulted from multiple volcanic activities which have occurred at Laochang deposit in Carboniferous.

As mentioned above, the stratabound ores host in the top of the two volcanic cycles (Figure 4). Li et al. [11] and our view infer that at least two main stages of mineralization occurred in stratabound ores, i.e., at the first dormant period of volcanic activity and at the second intermittent period of volcanism marked by the sediment influx. Liu et al. [61] obtained a Re-Os isochron age of $308 \pm 5 \mathrm{Ma}$ on galena and sphalerite from upper stratabound ores (1930 m mining tunnel), which is slightly younger than a SHRIMP zircon U-Pb age of $312 \pm 4$ Ma for the footwall basaltic tuff from $1840 \mathrm{~m}$ mining tunnel. This result demonstrated that the ages of upper stratabound mineralization are approximately similar/slightly younger than the footwall volcanic rocks in $1840 \mathrm{~m}$ mining tunnel [18]. In constrast, the timing of lower stratabound ores is still unclear. Chen et al. [60] obtained a SHRIMP zircon U-Pb age of $323.6 \pm 2.8 \mathrm{Ma}$ for the footwall tuff from $1725 \mathrm{~m}$ mining tunnel. More importantly, the geologic cross section shows that the orebodies are in conformity with the host volcanic rocks, occurring in bedded or bed-like form, lenticular and intercalated with sedimentary rocks, e.g., black shale, shallow marine, tuffite and siliceous rock, massive bioclastic limestone and biological fossils [62], which show the synvolcanogenic orgin. The presence of sulfide orebody underlying volcanic rocks place a maximum age for the lower stratabound mineralization (Figure 4). The timing of upper stratabound ore is considered as the minimum mineralization age (Figure 4). Therefore, the emplacement of stratabound mineralization is likely between $\sim 323 \mathrm{Ma}$ and $308 \mathrm{Ma}$. A similar age has been proposed for the Laochang stratabound mineralization by Hou et al. [2] and Deng et al. [40].

\subsection{Source of Metals}

The spatial relationship between the stratabound orebodies and the Cenozoic porphyry intrusion, coupled with the hydrothermal alteration assemblages, has led many authors to propose a genetic connection between the stratabound mineralization and the granitic porphyry magmatism [12,15-17]. They argue that the stratabound orebodies are a shallow product of the concealed porphyry-skarn Mo system. However, the significant difference between the $\mathrm{Pb}$ isotope signatures of stratabound ores and granitic porphyry (Figure 12A,B), together with very wide $\mathrm{Pb}$ isotope variation of stratabound ores, does not support a genetic relationship with the porphyry intrusion. Additionally, the data of trace elements in sphalerite and $\mathrm{Y} / \mathrm{Ho}$ ratio reported by Ye et al. [63], which basically preclude the ore-stage metals were derived from Cenozoic porphyry magmatism.

Interestingly, on the $\mathrm{Pb}-\mathrm{Pb}$ diagrams (Figure 12A,B), the $\mathrm{Pb}$ isotope signature of stratabound ore samples present good linear arrays $\left({ }^{206} \mathrm{~Pb} /{ }^{204} \mathrm{~Pb}\right.$ vs. ${ }^{207} \mathrm{~Pb} /{ }^{204} \mathrm{~Pb}$, correlation coefficient $\mathrm{R}^{2}=0.943$; ${ }^{207} \mathrm{~Pb} /{ }^{204} \mathrm{~Pb}$ vs. ${ }^{208} \mathrm{~Pb} /{ }^{204} \mathrm{~Pb}$, correlation coefficient $\mathrm{R}^{2}=0.984$ ), which are identical to those reported for the Dapingzhang and Keketale VMS deposits in China [64,65], as well as VMS deposits in the other parts of the world [66,67]. Moreover, the $\mathrm{Pb}$ isotope signatures define a well-correlated trend, which suggests a mixing of two distinct source components characterized by different $\mathrm{Pb}$ isotope compositions, i.e., the radiogenic $\mathrm{Pb}$-rich endmember and the nonradiogenic $\mathrm{Pb}$-rich reservoir. As mentioned above, volcanic rocks are reflected by high radiogenic $\mathrm{Pb}$ isotopic composition, and a portion of the $\mathrm{Pb}$ isotope signature of sulfide samples are similar to that of the host volcanic rocks (Figure 12A,B), thus, we consider that the radiogenic $\mathrm{Pb}$-rich metal stem from the host volcanic rocks. Moreover, Zhang et al. [68] demonstrate that the mantle reservoir of western Yunnan district is relatively enriched in low ${ }^{208} \mathrm{~Pb} /{ }^{204} \mathrm{~Pb}$ and ${ }^{207} \mathrm{~Pb} /{ }^{204} \mathrm{~Pb}$, and another small fraction of sulfide samples fall into that area in $\mathrm{Pb}-\mathrm{Pb}$ diagrams (Figure 12A,B). Therefore, a likely interpretation for the linear arrays of $\mathrm{Pb}$ isotope signatures show a mixed source, respectively, for leaching the volcanic rocks of the Yiliu Formation and mantle reservoir.

In summary, the $\mathrm{Pb}$ isotope compositions of sulfide samples from stratabound ores support that the host volcanic rocks of Yiliu Formation and the mantle reservoir were the main source of $\mathrm{Pb}$ in the Laochang district. Conversely, no $\mathrm{Pb}$ appears to have been sourced in the spatially associated 
Eocene granitic porphyry, as their $\mathrm{Pb}$ isotope compositions are significantly different from those of the sulfide samples.
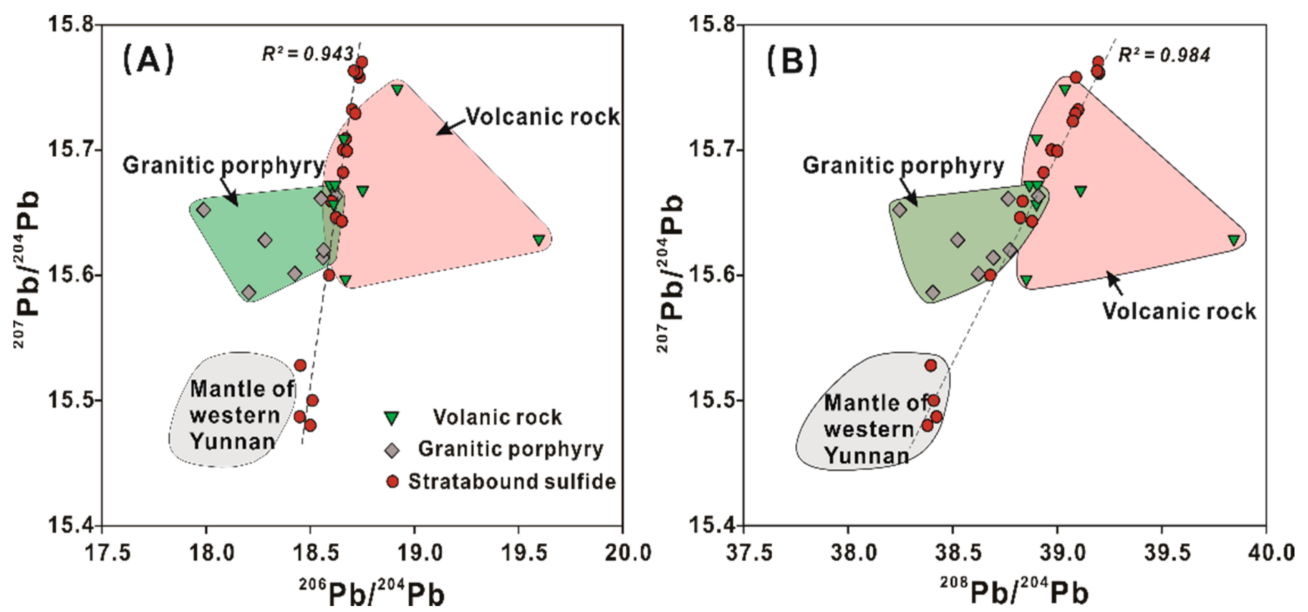

Figure 12. $\mathrm{Pb}$ isotopic compositions of granitic porphyry, volcanic rocks, and stratabound ore from the Laochang deposit. (A) Plots of ${ }^{206} \mathrm{~Pb} /{ }^{204} \mathrm{~Pb}$ vs. ${ }^{207} \mathrm{~Pb} /{ }^{204} \mathrm{~Pb}$. (B) Plots of ${ }^{208} \mathrm{~Pb} /{ }^{204} \mathrm{~Pb}$ vs. ${ }^{207} \mathrm{~Pb} /{ }^{204} \mathrm{~Pb}$. Data are listed in Table 4.

\subsection{Trace Element Constraints}

Trace element contents in sphalerite from different genetic type of deposit are diagnostic, under the assumption that no overprint has occurred [69-73]. The skarn deposits feature high Co and Mn; their distal character is reflected by low In. The syngenetic massive sulfides deposit is characterized by elevated In, Sn and Ga, whereas the MVT deposits are typically enriched in $\mathrm{Ge}, \mathrm{Cd}, \mathrm{Tl}$, and As [71]. Thus, the measured trace elements in sphalerite likely show promise as tracer for genetic type of mineral deposit. The genetic type of stratabound deposit can, to a large extent, be determined by comparing the trace element concentration in sphalerite.

Sphalerite from stratabound orebodies is characterized by low $\mathrm{Co}, \mathrm{Ni}$ and $\mathrm{Ge}$, which differs from the distal skarn deposits (Co $>200$ ppm, In $<10$ ppm), MVT and sandstone-hosted Pb-Zn deposits (Ge $>20 \mathrm{ppm}, \mathrm{Mn}<100 \mathrm{ppm}$ ), and they also contrast markedly with the magmatic-hydrothermal deposits of the Middle-Lower Yangtze River Valley metallogenic belt, China [63]; the sphalerite is relatively enriched in Fe, Mn, In and Ga, which show strong similarities with VMS deposits (In $>50$ ppm and $\mathrm{Mn}>1000 \mathrm{ppm}$ ) of southern China [69,71], as well as VMS deposits elsewhere in the world [70,73]. Furthermore, on trace discrimination diagrams of Fe-In, Mn-Fe, Mn/Fe-In, In/Cd-Fe, Fe-In/Ge, $\mathrm{Mn}-\mathrm{Co}$, and In-Mn (Figure 13), the samples from stratabound orebodies plot within the VMS deposits field (Sauda, Western Norway; Kaveltorp and Marketorp, South-Central Sweden; Cook et al. [70]) and are distinct from the epithermal deposits (Baia de Aries, Rosia Montana and Magura, SE Europe; Cook et al. [70]), magmatic hydrothermal vein type deposit (Jinbao, China; Zhou et al. [74]) and distal skarn deposit (Luziyuan and Hetaoping, China; Ye et al. [71]). In addition, they are also different from MVT (East Tennessee district, USA; Tres Marias mine, Mexico; Limei, Yutang, Niujiaotang, Mengxing, Huize, Nayongzhi and Tianbaoshan deposits, China; Cook et al. [70]; Ye et al. [71,75]; Wei et al. [76]) and sandstone-hosted $\mathrm{Pb}-\mathrm{Zn}$ deposits (Jinding, China; Ye et al. [71]). 

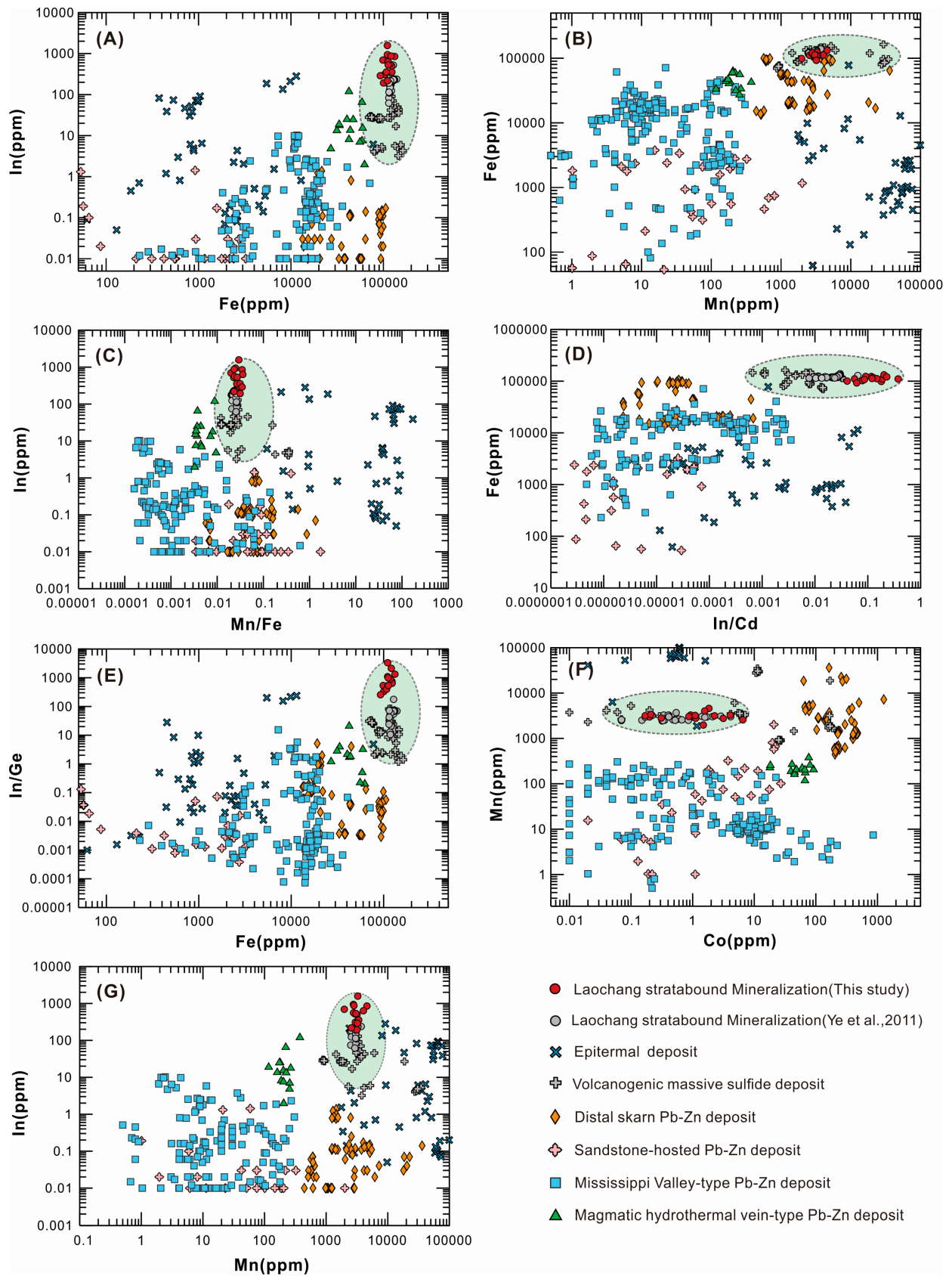

Figure 13. Binary plots of Fe vs. In (A), Mn vs. Fe (B), Fe vs. In/Ge (C), Mn vs. Co (D), Fe vs. In/Ge (E), Mn vs. Co (F) and Mn vs. In (G) in sphalerite from the Laochang stratabound ores and Mississippi Valley-type (MVT), volcanogenic massive sulfide (VMS), epithermal, distal skarn, Sandstone-hosted, magmatic hydrothermal vein-type $\mathrm{Pb}-\mathrm{Zn}$ deposits in China, NE Europe, Canada, Mexico and Japan. Note: Plots are based on data from Cook et al. [69], Ye et al. [71,75], Zhou et al. [74] and Wei [76].

Collectively, the trace element characteristic of the fifteen sphalerite samples from the stratabound ores are similar to that of the VMS deposits rather than magmatic-hydrothermal deposits, which exclude the Cenozoic concealed granitic porphyry as potential source rocks.

\subsection{Implications for Ore Genesis of Stratabound Ores}

Genesis of the stratabound ores in volcanic rocks at Laochang has been debated for many years $[13,14,17,77,78]$. Some authors interpreted the genesis of stratabound ores to be magmatichydrothermal deposit $[13,14]$ based on a limited database. Others hold the opinion that the stratabound 
ores is of syngenetic volcanogenic origin $[17,77]$. If the stratabound ores were genetically related to the concealed porphyry and thus interpreted as a magmatic-hydrothermal deposits, it should be characterized by: (a) Fault-controlled orebody showing clearly epigenetic origin; (b) timing of mineralization approximately contemporaneous with the emplacement age of granitic porphyry; (c) the majority of the metal derived from the coeval granitic porphyry. However, the stratabound ores is distinct from the magmatic hydrothermal deposit in: (a) The stratabound ores hosted in the top of two volcanic cycles, similar to the Tongchangjie and Dapingzhang VMS deposit in STMB, which would indicate that mineralization occurred at the intermittent stage of volcanic activity; (b) orebodies occurred mostly stratiform, stratoid, as lens or intercalated within sedimentary and volcano-sedimentary rocks like black shale, tuffite and siliceous rock, massive bioclastic limestone and biological fossils [62]; (c) abundant recrystallized colloidal pyrites with formation of atoll structures from colloform pyrite aggregates (Figure 6A,B), similar to that described from the Kuroko-style VMS deposits in Japan [79]; (d) the Pb isotopic compositions of sulfide samples from strataound ores is significantly different from the hidden granitic porphyry. In addition, the trace element in sphalerite from stratabound ores is enriched in $\mathrm{Fe}, \mathrm{Mn}, \mathrm{Cd}$, In and $\mathrm{Ga}$, which is significantly distinct from those of magmatic-hydrothermal deposit.

In summary, newly obtained zircon SHRIMP U-Pb geochronology, trace element in sphalerite and $\mathrm{Pb}$ isotopes, together with ore deposit geology and mineralogy, suggest stratabound ores should be classified as a VMS deposit.

\subsection{Tectonic Setting and Geodynamic Setting of VMS Deposit}

The Changning-Menglian Suture zone has experienced opening of the Changning-Menglian Paleo-Tethys, subduction of the oceanic plate, terrane-continent collision, and post-collisional uplift [80-82]. The presence of 349-331 Ma gabbros of ophiolite complex and the Middle Devonian deep water marine cherts, Eoalbaillella lilaensis radiolarians [23,24] suggest that opening of the Changning-Menglian Paleo-Tethys occurred during the Middle Devonian then spread, evolving into the one segment of the Paleo-Tethys main ocean $[4,83]$. Previous studies consider that subduction-related magmatism in Changning-Menglian Suture zone mainly occurred during the Late Carboniferous-Middle Permian [83-85]. Jian et al. [28] considered that the subduction of the Paleo-Tethys oceanic plate was generated in the middle Permian, as recorded by the meta-gabbros from the Damoguanfang supra-subduction zone (SSZ-type) ophiolites $(267.1 \pm 3.1 \mathrm{Ma}$ by zircon U-Pb). The Changning-Menglian Paleo-Tethys oceanic plate underneath the Simao block has resulted in the formation of Nanlinshan and Banpo mafic-ultramafic intrusions, which were emplaced at 298-292 Ma [27,86] and 295-286 Ma [28,86], respectively. Subduction is further evidenced by the presence of the subduction -related intrusive rock with SHRIMP U-Pb age of tonalite, microgabbro, plagioclase hornblendite and diabase from 306 to $281 \mathrm{Ma}$ in the north of this suture $[28,86]$. All evidences suggest that the initial subduction of the Changning-Menglian Paleo-Tethys oceanic plate was at Late Carboniferous ( 306 Ma).

Laochang district is located in the South Changning-Menglian suture, and the volcanic rocks in this study exhibit typical OIB-like geochemical signature, such as elevated HFSEs ( $\mathrm{Nb}, \mathrm{Ta}, \mathrm{Zr}$ and Hf) abundance, slight enrichment of LREE and depletion of $\mathrm{Ba}$ and $\mathrm{Sr}$ with obvious $\mathrm{Nb}$-Ta anomalies $\left((\mathrm{Nb} / \mathrm{La})_{\mathrm{N}}=0.87-1.11\right)$. Such characteristics suggest that the magma source is similar to typical oceanic island basalt [57]. In the $\mathrm{Ce} / \mathrm{Nb}$ vs. $\mathrm{Th} / \mathrm{Nb}$ and $\mathrm{Th} / \mathrm{Yb}$ vs. $\mathrm{Nb} / \mathrm{Yb}$ discrimination diagrams (Figure $14 \mathrm{~A}, \mathrm{~B}$ ), all samples plot in or near the field of OIB, and in the Ti/50-V-5 $\times \mathrm{Sc}$ and Ti/50-V-50 $\times$ Sm diagrams (Figure 14C,D), they plot in the fields of OIB $[87,88]$. Moreover, the OIB-like volcanic rocks intercalated with sedimentary rocks, e.g., black shale, siliceous rock, massive bioclastic limestone and fossils [62] and the continental substance were not observed in the overlying Carboniferous limestone and dolomite [89]. Thus, this suggest that the basalt were generated in the oceanic island setting (Figure 15A,B) [90]. Moreover, the OIB-like volcanic rocks were formed between $323 \mathrm{Ma}$ and $312 \mathrm{Ma}$, which could be approximately synchronous with the VMS mineralization at Laochang 
(Figure 15B). Thus, this suggest that the timing of stratabound mineralization precedes the earliest record for subduction of the Paleo-Tethys oceanic plate.
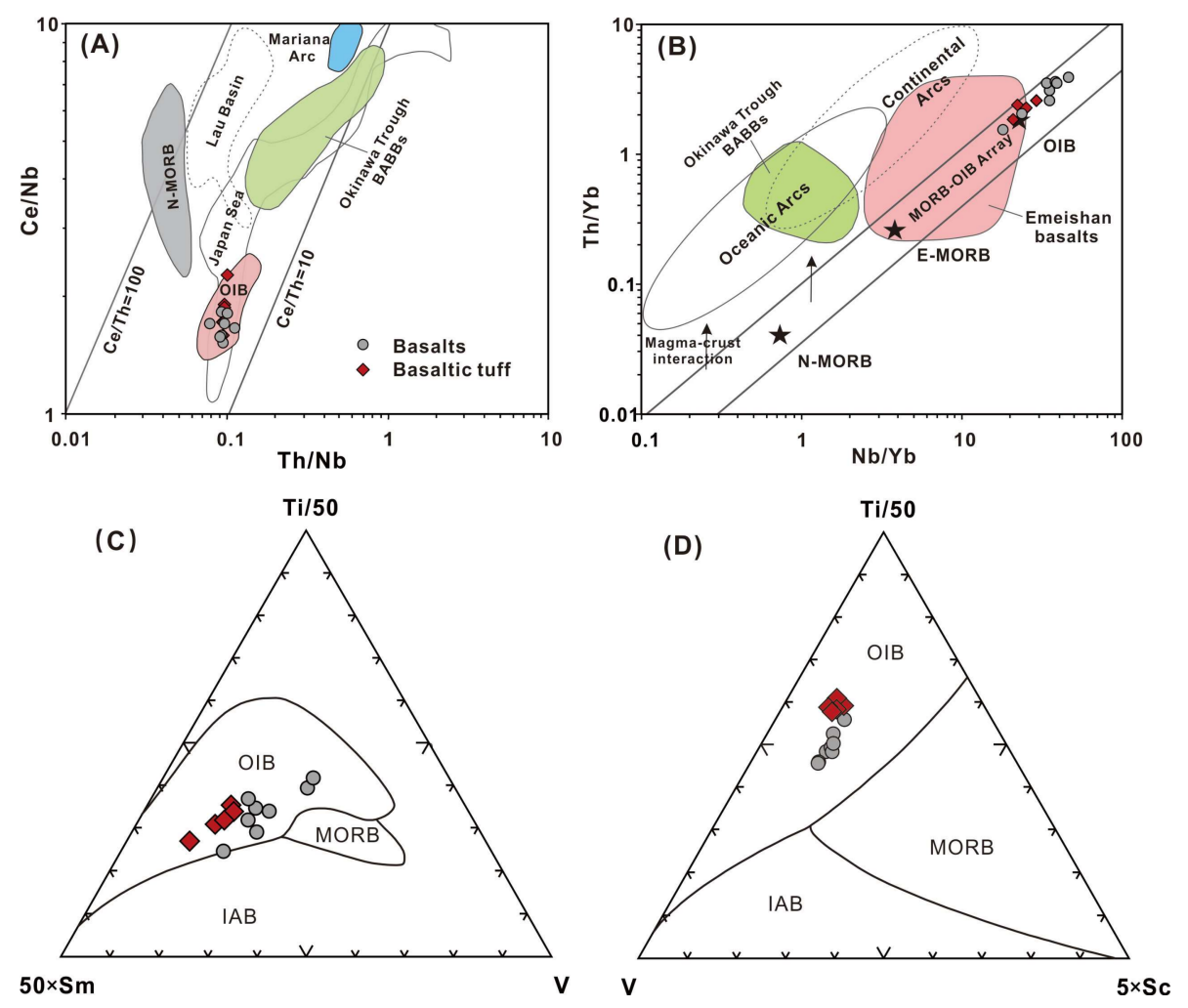

Figure 14. Discrimination diagrams of mantle source for the Laochang volcanic rocks. (A) Th/Yb vs. Ce/Nb diagram from Sandeman et al. [91] and Taylor and Martinez [92]; (B) $\mathrm{Nb} / \mathrm{Yb}$ vs. Th/ $\mathrm{Nb}$ diagram. Discrimination fields of oceanic arcs, continental arcs, Mariana Trough back-arc basin basalts (BABBs) and mid-ocean ridge basalt (MORB)—oceanic island basalt (OIB) mantle array are from Pearce [93-95]. (C) Ti/50-50 $\times \mathrm{Sm}-\mathrm{V}$ ternary diagram and (D) Ti/50-50 $\times \mathrm{Sm}-\mathrm{V}$ ternary diagram from Vermeesch et al. [87,88].

Collectively, all geochemical and geochronological evidences confirm that the Laochang VMS mineralization generated in oceanic island setting prior to the subduction of Changning-Menglian Paleo-Tethys Ocean, corresponding with the VMS mineralization associated with submarine volcanism around the world $[18,96]$. 
Early Carboniferous $\sim 323 \mathrm{Ma}$
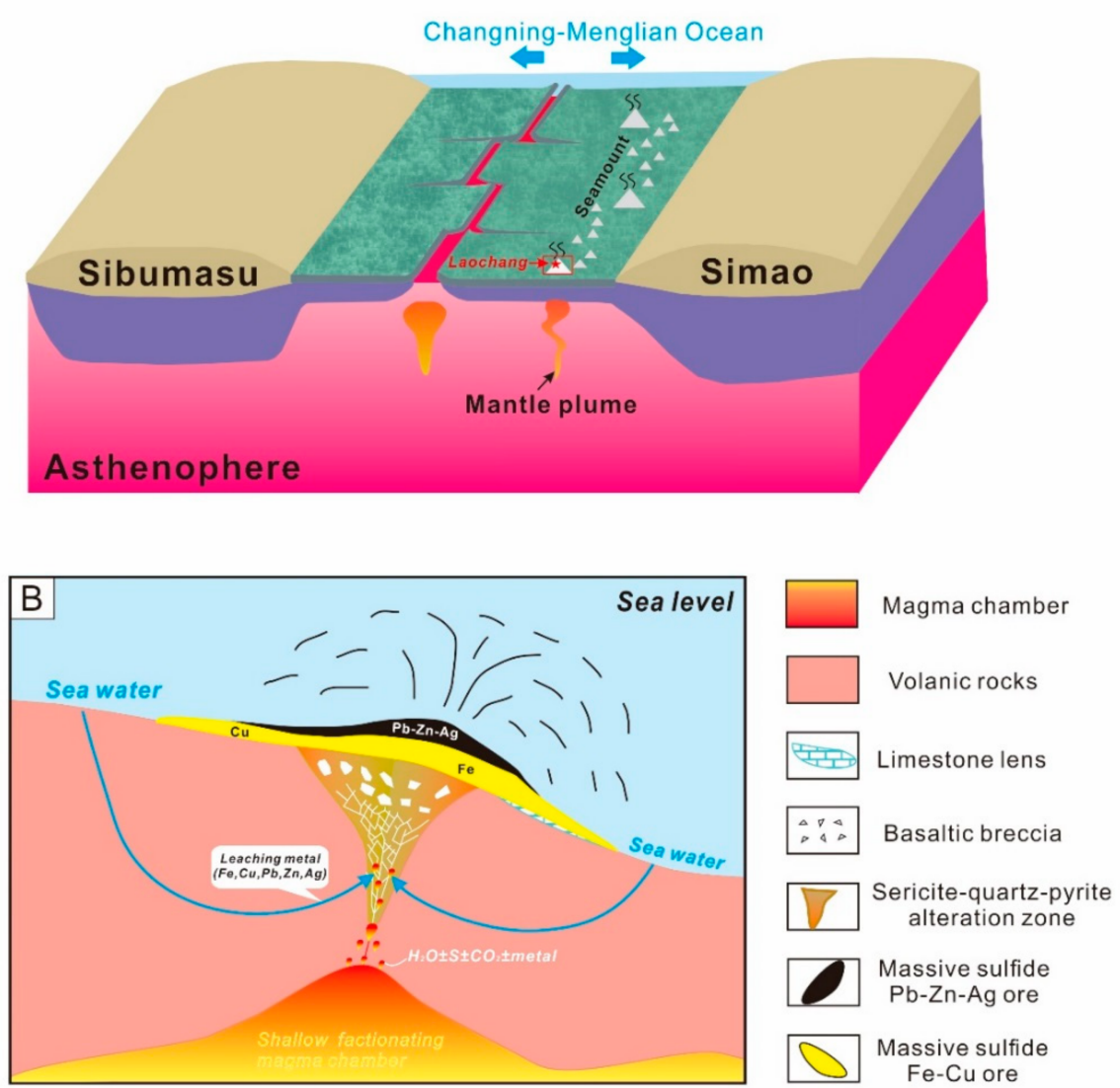

Figure 15. (A) General sketch shows the tectonic setting of the Laochang ore deposit. (B) Proposed genetic model for the Laochang $\mathrm{Ag}-\mathrm{Pb}-\mathrm{Zn}-\mathrm{Cu}$ deposit. High temperature, high salinity, metal-charged ( $\mathrm{Fe}, \mathrm{Cu}, \mathrm{Pb}, \mathrm{Zn}$, and $\mathrm{Ag}$ ) and $\mathrm{H}_{2} \mathrm{~S}$-rich fluids were degassed directly from the shallow (sub-volcanic) fractionating magma chamber, and subsequently ascended and combined with the infiltration of seawater leaching metals from host volcanic rocks; then metal-rich hydrothermal fluid mixed with cold seawater causing the precipitation of stringer, disseminated and massive sulfide ores.

\section{Conclusions}

To briefly summarize our main findings in the Laochang Ag-Pb-Zn-Cu deposit, we have shown the following:

1. Newly geochronological data show the basaltic tuff (SHRIMP zircon U-Pb $=312 \pm 4 \mathrm{Ma}$ ), combined with previous studies (zircon $\mathrm{U}-\mathrm{Pb}=323.6 \pm 2.8 \mathrm{Ma}$, Chen et al. [60]; galena and sphalerite Re-Os $=308 \pm 5 \mathrm{Ma}$, Liu et al. [61]), we consider that that the stratabound mineralization occur in the Late Paleozoic ( 323-308 Ma).

2. The trace element in sphalerite from stratabound ores is characterized by elevated Fe, In, Sn, and $\mathrm{Ga}$, similar to typical VMS deposit; and $\mathrm{Pb}$ isotope ratios in sulfides display a steep linear trend, indicating the $\mathrm{Pb}$ originated from multiple sources via the mixing effect of leaching between the host rock and mantle reservoir.

3. The combined evidence of geology, $\mathrm{Pb}$ isotope, trace elements in sphalerite, along with the geochronology suggested that the stratabound ores formed in Carboniferous at Laochang deposit would be better attributed to a VMS deposit. 
4. The volcanic rocks hosting the stratabound ore show elevated HFSEs $(\mathrm{Nb}, \mathrm{Ta}, \mathrm{Zr}$ and $\mathrm{Hf})$ abundance, slight enrichment of LREE and depletion of $\mathrm{Ba}$ and $\mathrm{Sr}$ with obvious $\mathrm{Nb}$-Ta anomalies. Such characteristics suggest that their magma is similar to typical oceanic island basalt, which suggests that Laochang VMS mineralization was generated in the oceanic island setting preceding the initial subduction of the Paleo-Tethys oceanic plate.

Author Contributions: C.W., L.Y. and Z.H. proposed and organized the project; C.W., Z.H. and W.G. discussed and designed and performed the experiment; C.W., Y.H. and Z.L. analyzed and interpreted the data; C.W. wrote the main manuscript; Z.H., L.Y. and J.Z. revised the main manuscript. All the authors discussed the study.

Funding: This research was financially supported by the National Natural Science of China (No. 41173063), the Sate Key Program of the Natural Science of China (Grant No. 41430315), National key research and development program (2017YFC0602502), the Natinal “973” Program of China (2014CB440906) and Guizhou Scientific and Technology Planing Project (QKHPTRC [2018]5626).

Acknowledgments: We thank for Zenglong Shi and Shaoping Jiang from Yunnan Lancang lead mine Ltd., for assistance during fieldwork. We thank Wenjun $\mathrm{Qu}, \mathrm{Mi}$ Chen and Yulong Yang for sample preparation, ICP-MS, SHRIMP analysis, respectively. We also thank Feng Li at the Kunming University of Science and Technology for his constructive review. Finally, we are grateful to the constructive reviews of three anonymous reviewers and Guest Editors Reinaldo Sáez and Felipe Gonzalez.

Conflicts of Interest: The authors declare no conflict of interest.

\section{References}

1. Sengor, A.M.C. Tectonics of the Tethysides: Orogenic collage development in a collisional setting. Ann. Rev. Earth Planet. Sci. 1987, 15, 213-244. [CrossRef]

2. Hou, Z.Q.; Zaw, K.; Pan, G.; Mo, X.; Xu, Q.; Hu, Y.; Li, X. Sanjiang Tethyan metallogenesis in S.W. China: Tectonic setting, metallogenic epochs and deposit types. Ore Geol. Rev. 2007, 31, 48-87. [CrossRef]

3. Deng, J.; Wang, C.M.; Li, G.J. Style and process of the superimposed mineralization in the Sanjiang Tethys. Acta Petrol. Sin. 2012, 28, 639-648. (In Chinese)

4. Deng, J.; Wang, Q.F.; Li, G.J.; Santosh, M. Cenozoic tectono-magmatic and metallogenic processes in the Sanjiang region, Southwestern China. Earth Sci. Rev. 2014, 138, 268-299. [CrossRef]

5. Wang, C.M.; Deng, J.; Carranza, E.J.M.; Santosh, M. Tin metallogenesis associated with granitoids in the southwest Sanjiang Tethyan Domain: Nature, types, and tectonic setting. Gondwana Res. 2014, 26, 576-593. [CrossRef]

6. Xue, B.G. Mineralization Characteristics of the Laochang Ag-Pb Polymetallic Deposit, Lancang. Miner. Resour. Geol. 1998, 12, 26-32. (In Chinese)

7. Chen, B.Y.; Wang, Z.R.; Peng, S.L. Study on the genesis of Laochang Ag-Pb-Zn-Cu Polymetallic deposit. Yunnan Geol. 2002, 21, 134-144. (In Chinese)

8. Li, F.; Lu, W.J.; Yang, Y.Z.; Tang, X.P.; Shi, Z.L. The Research of Crisis Miners Ore-Forming Regularity and Prospecting: On Yunnan Lancang Old Miners Bed for Example; Yunnan Science and Technology Press: Kunming, China, 2010; pp. 1-155. (In Chinese)

9. Yang, K.H.; Mo, X.X. Main features and genetical type of the Laochang volcanic Massive sulfide deposit Yunnan Province. Bull. Chin. Acad. Geol. Sci. 1993, 26, 79-96. (In Chinese)

10. Chen, M.; Huang, Z.L.; Luo, T.Y.; Yan, Z.F.; Long, H.S. Petrogenesis and tectonic significance of the Laochang basalt in western Yunnan Province, China. Acta Mineral. Sin. 2011, 31, 55-61. (In Chinese) [CrossRef]

11. Li, G.J.; Deng, J.; Wang, Q.F.; Liang, K. Metallogenic model for the Laochang Pb-Zn-Ag-Cu volcanogenic massive sulfide deposit related to a Paleo-Tethys OIB-like volcanic center, SW China. Ore Geol. Rev. 2015, 70, 578-594. [CrossRef]

12. Fan, C.J. Discussion on the origin and the regional geological background of Laochang $\mathrm{Pb}-\mathrm{Zn}$ deposits in Lancang country. Yunnan Geol. 1985, 4, 3-16. (In Chinese)

13. Mo, X.X.; Lu, F.X.; Shen, S.Y. Sanjiang Tethyan Volcanism and Related Mineralization; Geological Publishing House: Beijing, China, 1993; pp. 1-239. (In Chinese)

14. Hou, Z.Q.; Li, H.Y. A tentative discussion on the mantle plume tectonics and metallogenic system as exemplified by the Sanjiang Tethyan metallogenic domain. Miner. Depos. 1998, 17, 97-113. (In Chinese) 
15. Xue, B.G. The discussion of the gensis of Laochang Pb-Zn deposit in Lancang. Yunnan Geol. 1989, 8, 181-188. (In Chinese)

16. O'yang, C.P.; Xu, C.M. Geochemical features and genesis of the Laochang Diwa-type silver-lead ore deposit in Langchang, Yunnan, China. Geotecton. Metallog. 1991, 15, 317-326. (In Chinese)

17. Deng, X.D.; Li, J.W.; Zhao, X.F.; Qi, L. Re-Os and U-Pb geochronology of the Laochang Pb-Zn-Ag and concealed porphyry-skarn Mo mineralization along the Changning-Menglian suture, SW China: Implications for ore genesis and porphyry Cu-Mo exploration. Mineral. Depos. 2016, 51, 237-248. [CrossRef]

18. Franklin, J.M.; Gibson, H.L.; Jonasson, I.R.; Galley, A.G. Volcanogenic massive sulfide deposits. In 100th Anniversary Volume; Society of Economic Geologists: Littleton, CO, USA, 2005; pp. 523-560.

19. Leach, D.L.; Sangster, D.F.; Kelley, K.D.; Large, R.R.; Garven, G.; Allen, C.R.; Gutzmer, J.; Walters, S. Sediment-hosted lead-zinc deposits: A global perspective. In 100th Anniversary Volume; Hedenquist, J.W., Thompson, J.F.H., Goldfarb, R.J., Richards, J.P., Eds.; Society of Economic Geologists: Littleton, CO, USA, 2005; pp. 561-607.

20. Seedorff, E.; Dilles, J.H.; Proffett, J.M.; Einaudi, M.T.; Zurcher, L.; Stavast, W.; Johnson, D.A.; Barton, M.D. Porphyry deposits: Characteristics and origin of hypogene features. In 100th Anniversary Volume; Society of Economic Geologists: Littleton, CO, USA, 2005; pp. 251-298.

21. Sillitoe, R.H. Porphyry copper systems. Econ. Geol. 2010, 105, 3-41. [CrossRef]

22. Bozhko, N.A. The evolution of the mobile zones of Gondwana and Laurasia in the Late Precambrian. Tectonophysics 1986, 126, 125-135. [CrossRef]

23. Feng, Q.L.; Liu, B. A new Early Devonian radiolarian genus from western Yunnan. Sci. China Ser. B 1993, 36, 242-248. (In Chinese)

24. Duan, X.D.; Li, J.; Zeng, W.T.; Feng, W.J. The discovery of Ganlongtang tectonic melange in the middle section of Changning-Menglian zone. Yunnan Geol. 2006, 25, 53-62. (In Chinese)

25. Yu, S.Y.; Li, K.Q.; Shi, Y.P.; Zhang, H.H. A study on the granodiorite in the middle part of Lincang granite batholith. Yunnan Geol. 2003, 22, 426-442. (In Chinese)

26. Wei, J.Q.; Wang, X.D.; Zhuang, X.; Liu, Y.H. Zircon SHRIMP U-Pb dating of diorite among Jicha serpentine and Eza gabbro from Lancangjiang belt, Yunnan Province and its geological significance. Acta Petrol. Sin. 2008, 24, 1297-1301. (In Chinese)

27. Hennig, D.; Lehmann, B.; Frei, D.; Belyatsky, B.; Zhao, X.F.; Cabral, A.R.; Zeng, P.S.; Zhou, M.F.; Schmidt, K. Early Permian seafloor to continental arc magmatism in the eastern Paleo-Tethys: U-Pb age and $\mathrm{Nd}-\mathrm{Sr}$ isotope data from the southern Lancangjiang Zone, Yunnan, China. Lithos 2009, 113, 408-422. [CrossRef]

28. Jian, P.; Liu, D.Y.; Kröner, A.; Zhang, Q.; Wang, Y.Z.; Sun, X.M.; Zhang, W. Devonian to Permian plate tectonic cycle of the Paleo-Tethys Orogen in southwest China (II): Insights from zircon ages of ophiolites, arc/back-arc assemblages and within-plate igneous rocks and generation of the Emeishan CFB province. Lithos 2009, 113, 767-784. [CrossRef]

29. Wang, T.; Jahn, B.M.; Kovach, V.P.; Tong, Y.; Hong, D.W.; Han, B.F. Nd-Sr isotopic mapping of the Chinese Altai and implications for continental growth in the Central Asian Orogenic Belt. Lithos 2009, 110, 359-372. [CrossRef]

30. Li, G.Z.; Su, S.G.; Lei, W.Y.; Duan, X.D. Precise ID-TIMS zircon U-Pb age and whole rock geochemistry of the Nanlinshan mafic intrusion in the southern Lancangjiang arc terrane, Sanjiang area, SW China. Earth Sci. Front. 2011, 18, 206-212. (In Chinese)

31. Wang, C.M.; Deng, J.; Santosh, M.; McCuaig, T.C.; Lu, Y.J.; Carranza, E.J.M.; Wang, Q.F. Age and origin of the Bulangshan and Mengsong granitoids and their significance for post-collisional tectonics in the Changning-Menglian Paleo-Tethys Orogen. J. Asian Earth Sci. 2015, 113, 656-676. [CrossRef]

32. Dong, G.C.; Mo, X.X.; Zhao, Z.D.; Zhu, D.C.; Goodman, R.C.; Kong, H.L.; Wang, S. Zircon U-Pb dating and the petrological and geochemical constraints on Lincang granite in western Yunnan, China: Implications for the closure of the PaleoTethys Ocean. J. Asian Earth Sci. 2013, 62, 282-294. [CrossRef]

33. Peng, T.P.; Wang, Y.J.; Fan, W.M.; Liu, D.Y.; Shi, Y.M.; Miao, L.C. The SHRIMP zircon U-Pb dating of the felsic igneous rocks from Southern Lancangjiang and its tectonic implications. Sci. China Ser. D 2006, 10, 123-132. (In Chinese) 
34. Wang, Y.; Zhang, A.; Fan, W.; Peng, T.; Zhang, F.; Zhang, Y.; Bi, X. Petrogenesis of late Triassic post-collisional basaltic rocks of the Lancangjiang tectonic zone, southwest China, and tectonic implications for the evolution of the eastern Paleotethys: Geochronological and geochemical constraints. Lithos 2010, 120, 529-546. [CrossRef]

35. Peng, T.P.; Wilde, S.A.; Wang, Y.J.; Fan, W.M.; Peng, B.X. Mid-Triassic felsic igneous rocks from the southern Lancangjiang Zone, SW China: Petrogenesis and implications for the evolution of Paleo-Tethys. Lithos 2013, 168-169, 15-32. [CrossRef]

36. Nie, F.; Dong, G.C.; Mo, X.X.; Zhu, D.C.; Dong, M.L.; Wang, X. Geochemistry, zircon U-Pb chronology of the Triassic granites in the Changning-Menglian suture zone and their implications. Acta Petrol. Sin. 2012, 28, 1465-1476. (In Chinese)

37. He, F.X.; Liu, B.P. Recognition of ancient oceanic island in Paleo-Tethys, western Yunnan. J. China Univ. Geosci. 1993, 4, 23-29. (In Chinese)

38. Feng, Q.L. Stratigraphy of volcanic rocks in the Changning-Menglian Belt in southwestern Yunnan, China. J. Asian Earth Sci. 2002, 20, 657-664. [CrossRef]

39. Wu, H.R.; Boulter, C.A.; Ke, B.; Stow, D.A.V.; Wang, Z.C. The Changning-Menglian suture zone; a segment of the major Cathaysian-Gondwana divide in Southeast Asia. Tectonophysics 1995, 242, 267-280. [CrossRef]

40. Deng, J.; Wang, Q.F.; Li, G.J. Superimposed orogeny and composite metallogenic system: Case study from the Sanjiang Tethyan belt, SW China. Acta Petrol. Sin. 2016, 32, 2225-2247. (In Chinese)

41. Long, H.S. Geochronology and Geochemistry of the Laochang Large Silver Polymetallic Deposit, Yunnan Province, China. Ph.D. Thesis, Institute of Geochemistry, Chinese Academy of Science, Guiyang, China, 2009. (In Chinese)

42. Ye, Q.T.; Shi, G.H.; Ye, J.H.; Yang, C.Q. Geological Characteristics and Mineralogenic Series of the Lead-Zinc Deposits in Sanjiang Region; Science and Technology Publishing House: Beijing, China, 1992; pp. 1-120. (In Chinese)

43. Li, H.J.; Tian, X. The study on fluid inclusion and its ore-forming physicochemical conditions for Langcang $\mathrm{Pb}-\mathrm{Zn}$-Ag-Cu deposit. Miner. Resour. Geol. 1995, 9, 107-111. (In Chinese)

44. Li, F.; Lu, W.J.; Yang, Y.Z.; Chen, H.; Luo, S.L.; Shi, Z.L. The rock and ore-forming ages of the Laochang porphyry molybdenum deposit in Lancang Yunnan. Geoscience 2009, 23, 1049-1055. (In Chinese)

45. Yang, F.; Li, F.; Chen, H.; Xiao, J.; Zhao, X. Geochemistry and tectonic setting of the Laochang concealed granite porphyry in Lancang, Yunnan Province. Acta Petrol. Mineral. 2012, 31, 39-49. (In Chinese)

46. Gao, J.G. Research on the Synthetic Metallogenic Information and the Positioning Location and Quantitative Prediction of Resource Orientation for Lancang-Laochang Lead Zinc-Polymetallic Deposit. Ph.D. Thesis, Kumming University of Science and Technology, Yunan, China, 2006. (In Chinese)

47. Williams, I.S. U-Th-Pb geochronology by ion microprobe. Rev. Econ. Geol. 1998, 7, 1-35.

48. Black, L.P.; Kamo, S.L.; Allen, C.M.; Aleinikoff, J.N.; Davis, D.W.; Korsch, R.J.; Foudoulis, C. Temorai: A new zircon standard for Phanerozoic U-Pb geochemistry. Chem. Geol. 2003, 200, 155-170. [CrossRef]

49. Ludwig, K.R. Squid 1.02: A User's Manual; Berkeley Geochronology Center Specia Publication: Berkeley, CA, USA, 2001; Volume 2, pp. 1-21.

50. Goto, A.; Tatsumi, Y. Quantitative analysis of rock samples by an X-ray fluorescence spectrometer (I). Rigaku J. 1994, 11, 40-59.

51. Goto, A.; Tatsumi, Y. Quantitative analysis of rock samples by an X-ray fluorescence spectrometer (II). Rigaku J. 1996, 13, 20-39.

52. Liu, Y.S.; Gao, S.; Kelemen, P.B.; Xu, W.L. Recycled crust controls contrasting source compositions of Mesozoic and Cenozoic basalts in the North China Craton. Geochim. Cosmochim. Acta 2008, 72, 2349-2376. [CrossRef]

53. Qi, L.; Hu, J.; Gregoire, D.C. Determination of trace elements in granites by inductively coupled plasma mass spectrometry. Talanta 2000, 51, 507-513.

54. Belshaw, N.S.; Freedman, P.A.; O’Nions, R.K.; Frank, M.; Guo, Y. A new variable dispersion double-focusing plasma mass spectrometer with performance illustrated for Pb isotopes. Int. J. Mass Spectrom. 1998, 181, 51-58. [CrossRef]

55. Hofmann, A.W. Chemical differentiation of the Earth: The relationship between mantle, continental crust, and oceanic crust. Earth Planet. Sci. Lett. 1988, 90, 297-314. [CrossRef]

56. Niu, Y.L.; Batiza, R. Trace element evidence from seamounts for recycled oceanic crust in the eastern equatorial Pacifc mantle. Earth Planet. Sci. Lett. 1997, 148, 471-484. [CrossRef] 
57. Sun, S.S.; Mcdonough, W.F. Chemical and isotopic systematics of oceanic basalts: Implications for mantle composition and processes. Geol. Soc. Lond. Spec. Publ. 1989, 42, 313-345. [CrossRef]

58. Xu, C.M.; Ou'yang, C.P. A study on the genesis of the Ag-Pb-Zn deposit in Laochang, Lancang, Yunnan. J. Guilin Coll. Geol. 1991, 11, 245-252. (In Chinese)

59. Zhao, X.Y.; Li, F.; Yang, F. Isotopic geochemical evidence of the sources of ore-forming materials for the Laochang deep porphyry $\mathrm{Mo}(\mathrm{Cu})$ deposit in Lancang, Yunnan. Acta Petrol. Mineral. 2012, 31, 712-722. (In Chinese)

60. Chen, M.; Huang, Z.L.; Luo, T.Y.; Yan, Z.F.; Long, H.S. SHRIMP dating and its geological significance of zircon in volcanic from Laochang large silver-lead-zinc deposit in western Yunnan Province, China. Acta Miner. Sin. 2010, 30, 456-462. (In Chinese)

61. Liu, Y.Y.; Qi, L.; Gao, J.F.; Ye, L.; Huang, Z.L.; Zhou, J.X. Re-Os dating of galena and sphalerite from lead-zinc sulfide deposits in Yunnan Province, SW China. J. Earth Sci. 2015, 26, 343-351. [CrossRef]

62. Han, N.R.; O'yang, C.P.; Li, W.H.; Li, R.L. Current opinion in the Laochang Carboniferous-Permian strata, Lancang, Yunnan. J. Stratigr. 1991, 1, 56-58. (In Chinese)

63. Ye, L.; Gao, W.; Yang, Y.L.; Liu, T.G.; Peng, S.S. Trace elements in sphalerite in Laochang Pb-Zn polymetallic deposit, Lancang, Yunnan Province. Acta Petrol. Sin. 2012, 28, 1362-1372. (In Chinese)

64. Wan, B.; Zhang, L.; Xiao, W.J. Geological and geochemical characteristics and ore genesis of the Keketale VMS $\mathrm{Pb}-\mathrm{Zn}$ deposit, Southern Altai Metallogenic Belt, NW China. Ore Geol. Rev. 2010, 37, 114-126. [CrossRef]

65. Zhu, W.G.; Zhong, H.; Yang, Y.J.; Ren, T. The origin of the Dapingzhang volcanogenic Cu-Pb-Zn ore deposit, Yunnan province, SW China: Constraints from host rock geochemistry and ore Os-Pb-S-C-O-H isotopes. Ore Geol. Rev. 2016, 75, 327-344. [CrossRef]

66. Mortensen, J.K.; Hall, B.V.; Bissig, T.; Oliver, J.; Rhys, D.A.; Ross, K.V.; Gabites, J.E. Age and paleotectonic setting of volcanogenic massive sulfide deposits in the Guerrero Terrane of central Mexico: Constraints from $\mathrm{U}-\mathrm{Pb}$ age and $\mathrm{Pb}$ isotope studies. Econ. Geol. 2008, 103, 117-140. [CrossRef]

67. Lode, S.; Piercey, S.J.; Layne, G.D.; Piercey, G.; Cloutier, J. Multiple sulphur and lead sources recorded in hydrothermal exhalites associated with the Lemarchant volcanogenic massive sulphide deposit, central Newfoundland, Canada. Miner. Depos. 2017, 52, 1-24. [CrossRef]

68. Zhang, Q.; Pan, J.Y.; Liu, J.J.; Shao, S.X.; Liu, Z.H. Determination and application of the upper mantal lead composition in western Yunnan. Geol. Geochem. 2002, 30, 1-6. (In Chinese)

69. Zhang, Q. Trace elements in galena and sphalerite and their geochemical significance in distinguishing the genetic types of Pb-Zn ore deposits. Chin. J. Geochem. 1987, 6, 177-190.

70. Cook, N.J.; Ciobanu, C.L.; Pring, A.; Skinner, W.; Shimizu, M.; Danyushevsky, L.; Saini Eidukat, B.; Melcher, F. Trace and minor elements in sphalerite: A LA-ICPMS study. Geochim. Cosmochim. Acta 2009, 73, 4761-4791. [CrossRef]

71. Ye, L.; Cook, N.J.; Ciobanu, C.L.; Liu, Y.P.; Zhang, Q.; Liu, T.G.; Gao, W.; Yang, Y.L.; Danyushevskiy, L. Trace and Minor Elements in Sphalerite from Base Metal Deposits in South China: A LA-ICP-MS Study. Ore Geol. Rev. 2011, 39, 188-217. [CrossRef]

72. Belissont, R.; Boiron, M.C.; Luais, B.; Cathelineau, M. LA-ICP-MS analyses of minor and trace elements and bulk Ge isotopes in zoned Ge-rich sphalerites from the Noailhac-Saint-Salvy deposit (France): Insights into incorporation mechanisms and ore deposition processes. Geochim. Cosmochim. Acta 2014, 126, 518-540. [CrossRef]

73. Frenzel, M.; Hirsch, T.; Gutzmer, J. Gallium, germanium, indium, and other trace and minor elements in sphalerite as a function of deposit type-A meta-analysis. Ore Geol. Rev. 2016, 76, 52-78. [CrossRef]

74. Zhou, Z.B.; Wen, H.J.; Qin, C.; Liu, L. Geochemical and isotopic evidence for a magmatichydrothermal origin of the polymetallic vein-type $\mathrm{Zn}-\mathrm{Pb}$ deposits in the northwest margin of Jiangnan Orogen, South China. Ore Geol. Rev. 2017, 86, 673-691. [CrossRef]

75. Ye, L.; Li, Z.L.; Hu, Y.S.; Huang, Z.L.; Zhou, Z.J.; Fan, H.F.; Danyushevskiy, L. Trace element in sulfide from Tianbaoshan $\mathrm{Pb}-\mathrm{Zn}$ deposit, Sichuan province, China: A LA-ICPMS study. Acta Petrol. Sin. 2016, 32, 3377-3393. (In Chinese)

76. Wei, H.T. Mineralization of the Huayuan Pb-Zn Orefield Western Hunan. Ph.D. Thesis, Central South University, Hunan, China, 2017. (In Chinese) 
77. Wang, Z.R.; Wu, Y.Z.; Duan, J.R.; Chen, X.H.; Peng, S.L.; Liu, S.N.; Hu, X.Z. The Metallogensis of Lancang rift and the genesis of Laochang $\mathrm{Cu}-\mathrm{Pb}-\mathrm{Ag}$ deposit in Western Yunnan. Geol. Explor. Non-Ferrous Met. 1992, 1, 207-215. (In Chinese)

78. Wang, Z.R.; Huang, Z.; Peng, S.L.; Chen, S.L.; Hu, X.Z. Genesis and metallogenic model of Laochang type silver multimetal massive sulfide deposits in Lancang, Yunnan Province. Trans. Nonferr. Met. Soc. Chin. 1997, 7, 1-6. (In Chinese)

79. Yui, S. Textures of some Japanese Besshi-type ores and their implications for Kuroko deposits. Econ. Geol. Monogr. 1983, 5, 231-240.

80. Liu, B.; Feng, Q.L.; Fang, N. Tectonic evolution of the Palaeo-Tethys in Changning-Menglian belt and adjacent regions, western Yunnan. J. China Univ. Geosci. 1991, 2, 18-28. (In Chinese)

81. Ueno, K.; Wang, Y.; Wang, X. Fusulinoidean faunal succession of a Paleo-Tethyan oceanic seamount in the Changning-Menglian Belt, West Yunnan, Southwest China: An overview. Island Arc 2003, 12, 145-161. [CrossRef]

82. Deng, J.; Yang, L.Q.; Wang, C.M. Research advance of superimposed orogenesis and metallogenesis in the Sanjiang Tethys. Acta Petrol. Sin. 2011, 27, 2501-2509. (In Chinese)

83. Deng, J.; Wang, C.M.; Zi, J.W.; Xia, R.; Li, Q. Constraining subduction-collision processes of the Paleo-Tethys along the Changning-Menglian Suture: New zircon U-Pb ages and $\mathrm{Sr}-\mathrm{Nd}-\mathrm{Pb}-\mathrm{Hf}-\mathrm{O}$ isotopes of the Lincang Batholith. Gondwana Res. 2018, 62, 75-92. [CrossRef]

84. Heppe, K.; Helmcke, D.; Wemmer, K. The Lancang River zone of southwestern Yunnan, China: A questionable location for the active continental margin of Paleo-Tethys. J. Asia Earth Sci. 2007, 30, 706-720. [CrossRef]

85. Bi, L.S. Metamorphism and Deformation Characteristics of Metamorphic Rocks in Shangyun-Huimin Section of Changning-Menglian Suture, Yunnan. Master's Thesis, China University of Geosciences, Beijing, China, 2014. (In Chinese)

86. Li, G.Z.; Su, S.G.; Duan, X.D. Precise ID-TIMS zircon U-Pb age, whole rock geochemistry and plate tectonic setting of the Banpo Complex in the south Lancangjiang arc terrane, Sanjiang area, SW China. Earth Sci. Front. 2012, 19, 96-109. (In Chinese)

87. Vermeesch, P. Tectonic discrimination of basalts with classification trees. Geochim. Cosmochim. Acta 2006, 70, 1839-1848. [CrossRef]

88. Vermeesch, P. Tectonic discrimination diagrams revisited. Geochem. Geophy. Geosyst. 2006, 7, 1-55. [CrossRef]

89. Zhang, Q.; Zhou, D.J.; Zhao, D.S.; Peng, X.J.; Luo, W.L.; Liu, X.P. Wilson Cycle of the Paleo-Tethyan Orogenic Belt in Western Yunnan: Record of Magmatism and Discussion on Mantle Processes. Acta Petrol. Sin. 1996, 12, 17-28. (In Chinese)

90. Gao, J.; Klemd, R.; Zhang, L.; Wang, Z.; Xiao, X. P-T path of high-pressure/low-temperature rocks and tectonic implications in the western Tianshan Mountains, NW China. J. Metamorph. Geol. 1999, 17, 621-636. [CrossRef]

91. Sandeman, H.A.; Hanmer, S.; Tella, S.; Armitage, A.A.; Davis, W.J.; Ryand, J.J. Petrogenesis of Neoarchaean volcanic rocks of the MacQuoid supracrustal belt: A backarc setting for the northwestern Hearne subdomain, western Churchill Province, Canada. Precambrian Res. 2006, 144, 126-139. [CrossRef]

92. Taylor, B.; Martinez, F. Back-arc basin basalt systematics. Earth Planet. Sci. Lett. 2003, 210, 481-497. [CrossRef]

93. Pearce, J.A.; Stern, R.J.; Bloomer, S.H.; Fryer, P. Geochemical mapping of the Mariana Arc-Basin System: Implications for the nature and distribution of subduction components. Geochem. Geophy. Geosyst. 2005, 6, 1-27. [CrossRef]

94. Pearce, J.A. Geochemical fingerprinting of oceanic basalts with applications to ophiolite classification and the search for Archean oceanic crust. Lithos 2008, 100, 14-48. [CrossRef]

95. Pearce, J.A. Immobile Element fingerprinting of ophiolites. Elements 2014, 10, 101-108. [CrossRef]

96. Franklin, J.M.; Lydon, J.W.; Sangster, D.F. Volcanic-associated massive sulfide deposits. In 75th Anniversary Volume; Society of Economic Geologists: Littleton, CO, USA, 1981; pp. 485-627.

(C) 2018 by the authors. Licensee MDPI, Basel, Switzerland. This article is an open access article distributed under the terms and conditions of the Creative Commons Attribution (CC BY) license (http:/ / creativecommons.org/licenses/by/4.0/). 